\title{
Translating the Kampala Convention into practice: A stocktaking exercise*
}

In 2016, the International Committee of the Red Cross (ICRC) carried out a study to take stock of current progress in implementing the African Union Convention for the Protection and Assistance of Internally Displaced Persons in Africa (the Kampala Convention). As the first ever legally binding international instrument of its kind, the Kampala Convention represents a significant step forward in reaffirming the rights of internally displaced persons (IDPs) in the face of a growing displacement problem in Africa. The stocktaking exercise grew because of the recognition of the value of the Kampala Convention and the urgent need to make it as effective as possible. The ICRC was involved from the outset in the drafting of the Kampala Convention and, since its adoption, has been working on promoting its ratification and implementation. The stocktaking exercise, therefore, is part of the ICRC's continuous support to the Kampala Convention. It is also an additional step within the framework of the ICRC's long-term operational engagement in addressing the needs of the displaced and their host communities affected by armed conflict and other situations of violence in Africa.

At the origin of the stocktaking exercise was also the observation that several States have undertaken-or are undertaking-important action to domesticate and operationalize the Kampala Convention, but they have tended to do so in isolation. The ICRC felt there was a need to compile the diverse experiences of States in order to bolster efforts to fully implement the Convention, by allowing States to learn from each other about how the Convention can work best.

* The complete report is available online at: https://shop.icrc.org/translating-the-kampala-convention-intopractice-2636.html. 
The study examined the practice of twenty-five African countries in which the ICRC is operating - these include not only States party to the Kampala Convention, but also other States not yet party who have taken action on internal displacement in the form of normative, policy or concrete measures. The focus has been on those obligations that are based in international humanitarian law or touch on humanitarian issues that the ICRC encounters in operations across Africa.

The findings were published in a report that identifies lessons learned, best practices and key challenges in States' efforts to meet their obligations towards IDPs, as provided in the Kampala Convention. The report offers recommendations to States and other actors concerned (African Union, Regional Economic Communities, UN agencies, civil society organizations, etc.) on how to translate the Kampala Convention into real improvements for IDPs.**

The report is being used by ICRC delegations in Africa in bilateral discussions with States on their obligations to protect and assist IDPs, and to provide them with durable solutions. It is also used to support the adoption by States of national legal frameworks and policies as part of their responses to situations of internal displacement. At the continental level, the report informs the ICRC's long-standing cooperation with the African Union and sub-regional forums (e.g. the Intergovernmental Authority on Development and the Economic Community of West African States) on promoting ratification of the Kampala Convention and strengthening its implementation. For example, the report served as a starting point for discussions among experts during the first meeting of the Conference of States Party to the Kampala Convention that was held in Harare in April 2017. According to the framework of the Plan of Action adopted by the Conference, the ICRC is to support further initiatives to enhance awareness of the Kampala Convention and facilitate the sharing of experience and expertise among States on its implementation.

The report's findings and recommendations are also proving to be useful in the ICRC's dialogue with States in other regions beyond Africa, insofar as they provide examples of measures that States can adopt to address internal displacement more effectively at the national and regional levels.

\section{Executive summary}

The displacement of millions of people within their own countries, whether due to natural disasters, armed conflict or other situations of violence, became a pressing humanitarian concern in the second half of the twentieth century. The number of internally displaced people (IDPs) has continued to grow in this new century, resulting in severe humanitarian, social and economic costs.

** At the time of writing, the report is available in English, French, Spanish and Portuguese. Translation into Arabic is forthcoming. In addition, the Executive Summary of the report is available in Arabic and Russian. 
Africa is a continent especially affected by this trend. In response to the challenge of preventing and addressing internal displacement on the continent, African States joined forces through the African Union (AU) to create the African Union Convention for the Protection and Assistance of Internally Displaced Persons in Africa (the Kampala Convention, or the Convention) in 2009. This innovative treaty, the world's first ever legally-binding instrument on IDPs, entered into force in 2012, after 15 African States ratified it. Today, 25 African States are party to the Kampala Convention, while another 18 have signed but not yet ratified it.

The International Committee of the Red Cross (ICRC) launched a stocktaking exercise to support the efforts of the AU, Regional Economic Communities (RECs), Regional Mechanisms for Conflict Prevention, Management and Resolution (RMs), and States party to the Kampala Convention in monitoring and effectively implementing the Convention. Our aim in undertaking this exercise is simple: to help increase the Convention's effectiveness in reducing internal displacement caused by armed conflict and other situations of violence and in improving protection of and assistance to IDPs in Africa.

The ICRC has long worked to protect and assist IDPs around the world, as part of our mandate to help people affected by armed conflict and other situations of violence. The ICRC has also been engaged from the outset in supporting the Kampala Convention. We were involved in the drafting of the Convention, providing legal advice relating to international humanitarian law (IHL) and supporting the negotiation process leading to the adoption of the Convention in October 2009. Since then, the ICRC has been working closely with the AU Commission (AUC) and African States to encourage and support ratification, national implementation and adoption of practical measures for the operationalization of the Kampala Convention. To this end, we offer legal advice on ways in which the Convention can be adopted and domestic normative frameworks to implement the Convention strengthened. In addition, in our operational dialogue with States across Africa, we recommend concrete measures that can be taken by States to adopt and implement the Convention.

The ICRC has for several decades produced tools that provide technical support and guidance to States on the national implementation of IHL and other relevant legal frameworks. The ICRC capitalized on this expertise and experience in carrying out the present stocktaking exercise. In addition, we were able to benefit from our field presence in Africa, where ICRC delegations in 29 countries carry out protection and assistance activities for IDPs, host communities and all those suffering the consequences of armed conflict or other situations of violence.

Throughout the first half of 2016, ICRC delegations across Africa provided updates and analysis on national developments relating to IDPs including States' latest actions to join, nationally implement and operationalize the Kampala Convention. These included States that have ratified the Kampala Convention as well as States that have not, but have adopted domestic normative frameworks or policies on the protection of IDPs, based on provisions of the 1998 Guiding Principles on Internal Displacement (the Guiding Principles) and two of the Great 
Lakes Pact Protocols. Some States that are facing situations of internal displacement, but have no formal domestic framework in place, were also considered.

An independent consultant commissioned by the ICRC compiled and analysed this field input and drafted Findings (in the form of lessons learned, some examples of good practices and key challenges) and Recommendations. These reflect the analysis of State practice in 25 African countries.

The Findings provide a picture of the current level of operationalization of the Kampala Convention. They outline States' efforts to discharge their responsibilities related to preventing and addressing internal displacement.

The Recommendations, intended for States but also for other organizations (e.g. AU, RECs and RMs, the UN, the ICRC and civil society organizations), are based on the Findings, as well as on additional research and consultations within the ICRC and with selected external stakeholders. They are structured as proposed actions to address challenges in implementing the Convention, capturing insight into ways in which current implementation of the Convention can be strengthened. The Recommendations are all without prejudice to the duty of States to carry out their respective obligations under international and domestic law.

The focus of the stocktaking exercise, and hence of this report, has been on those Kampala Convention obligations that are directly drawn from IHL and/or relate to humanitarian issues that the ICRC encounters in operations across Africa

In the writing of this report, we have endeavoured to keep the following questions in mind:

- What impact does the Kampala Convention have on the ground?

- What difference can it make in the lives of IDPs?

- What more needs to be done - by States, the AUC, RECs, RMs, the ICRC and other organizations and humanitarian actors - for the full implementation of the Kampala Convention to become a reality?

The report contains more than 80 Findings and 25 Recommendations. They are grouped under five main headings, according to the legal obligations and related measures required for their implementation:

1. Prevention

2. Planning, management and monitoring of protection and assistance activities

3. Providing adequate humanitarian assistance to IDPs

4. Protection of IDPs

5. Durable solutions for IDPs

The ICRC hopes that each of these Findings and Recommendations will be of interest to some States, depending on their own particular approach to the Kampala Convention. Several cross-cutting themes emerged in the formulation of the Findings and Recommendations, of which three merit particular mention:

1. The importance for States and other actors of engaging in dialogue with IDP communities in order to ensure their meaningful participation in decisionmaking on law, policies and programmes that affect them; 
2. The urgent need for ensuring access of IDPs to essential services such as health care and education;

3. The vital roles the AUC - and RECs and RMs - will play in the future in reinforcing the efforts of AU Member States to fully implement the Kampala Convention.

As part of the lessons learned drawn from the stocktaking exercise, the report underlines that efforts must be made before a crisis occurs to ensure that obligations under the Kampala Convention are translated into domestic law. This includes putting in place the necessary structures with mandates and resources to respond to the protection and assistance needs of IDPs. Effective coordination between the different ministries and government agencies concerned, as well as between the central, regional and local levels of public authorities, is crucial. In particular, experience reveals the importance of ensuring an inclusive process that engages all key domestic actors, starting with IDPs and host communities, who need to be involved in consultations, information-sharing and decision-making.

When it comes to ensuring access for IDPs to essential goods and basic services (e.g. health care, education and family tracing and reunification services), the lack of human and financial resources is often an obstacle for States to fulfil their primary obligations. Thus, effective access to IDPs by humanitarian organizations is a key factor in meeting the needs of those IDPs. Equally important is a commitment by public authorities and international actors to abide by humanitarian principles in providing assistance to IDPs.

On ensuring effective protection of IDPs, the report explores the challenges of striking the right balance between humanitarian and security considerations in regulating the movement of IDPs, as well as those of maintaining the strictly civilian and humanitarian character of IDP settings. On another note, the difficulties often faced by IDPs in obtaining official documents (e.g. personal identity documents) have an impact on their ability to access basic services and livelihood options. One important lesson learned is that efficient strategies for providing or replacing such documents deliver dividends in responding to urgent humanitarian needs.

When an armed conflict is ongoing, measures can and, in many cases, must be taken, by States and other parties to the conflict, to prevent displacement from occurring in the first place. This is especially true in ensuring respect for IHL and increasing efforts to protect civilians and limit the harm to which they are exposed. In practice, violations of IHL continue to be a major cause of conflictrelated internal displacement in Africa. The challenge here is to strengthen States' commitment (and capacity) to respect and ensure respect for IHL.

Finally, concerning the important role played by the AU, RECs and RMs on the way forward, the report confirms the need for further coordinated efforts to increase awareness of internal displacement issues and to promote the Kampala Convention among AU Member States.

Today, the Kampala Convention provides a comprehensive framework that has already begun to bring concrete improvements to the daily lives of many IDPs in 
Africa. To realize its full potential, however, it needs to be systematically and comprehensively translated into practice by African States. The hope is that this report will contribute to the important work of fully operationalizing the Kampala Convention, to the benefit of current and future IDPs in Africa.

\section{List of recommendations}

The full set of the report's recommendations is compiled here for ease of reference. Each recommendation and its supporting rationale can be reviewed in context within the report.

\section{Prevention}

\section{For States}

Recommendation 1: States that have not yet done so, should expedite their ratification of, or accession to, the Kampala Convention.

Recommendation 2: States party to the Kampala Convention should initiate and complete actions to incorporate treaty obligations in domestic law and policy processes, including criminal prohibitions, requesting advice and technical support if/as needed.

Recommendation 3: States should take steps to promote knowledge of the Kampala Convention by all the actors concerned, including IDPs themselves, host communities, civil society and public authorities, at central, regional and local levels.

Recommendation 4: States should ensure that all relevant public authorities including armed and security forces - are fully informed of their obligations and instructed to respect and ensure respect for international humanitarian law.

\section{For other actors}

Recommendation 5: International and humanitarian organizations should continue to offer technical advice and support to AU Member States, not only for ratification of the Kampala Convention, but also for the full range of domestic implementation measures required under national legal and policy frameworks.

Recommendation 6: The AUC, RECs, RMs, and other organizations with expertise in this domain should expand public awareness-raising and capacity-building activities on the Kampala Convention, in coordination with States and local civil society actors. The African Commission on Human and Peoples' Rights (ACHPR) and its special rapporteur on refugees, asylum seekers and internally displaced persons can also play a part in this regard, in accordance with their mandates and the role attributed to them by the Convention.

Recommendation 7: The AUC and AU Member States should ensure that the first Conference of States Parties takes place as soon as possible and adopts a 
comprehensive plan of action/road map on the operationalization of the Kampala Convention.

2. Planning, management and monitoring of protection and assistance activities

\section{For States}

Recommendation 8: States should take steps to ensure that the designated coordinating authority or body has the necessary mandate and legitimacy to mobilize all ministries and agencies concerned, and is granted adequate resources (human and financial) to function effectively.

Recommendation 9: Public authorities should develop adequate capacities at all levels to gather and maintain solid and current data on the needs, vulnerabilities and capacities of IDPs, as well as on durable solutions, including disaggregated data (by sex, age and other relevant factors).

Recommendation 10: Public authorities should proactively ensure consultation and active engagement of IDPs and host communities in order to ensure their participation in decision-making on actions undertaken on their behalf. This engagement should take into account the diverse profiles of the displaced population (e.g. sex, age and other factors).

Recommendation 11: Public authorities at all levels with responsibilities for delivering assistance should establish mechanisms for monitoring short and longer-term outcomes. These should incorporate appropriate elements of accountability to IDPs.

\section{For other actors}

Recommendation 12: When supporting States to develop laws and policies, including national strategies on internal displacement, other actors should favour approaches that ensure the maximum ownership on the part of the authorities.

\section{Providing adequate humanitarian assistance to IDPs}

\section{For States}

Recommendation 13: Assessments should look at the needs and capacities of IDPs, as well as those of host communities, local authorities and services, to continuously inform the design of programme responses.

Recommendation 14: States should develop capabilities to foresee, assess and respond effectively to the multiple needs of IDPs.

Recommendation 15: States should ensure that all relevant public authorities including armed and security forces - are fully informed of their obligations and instructed to facilitate rapid and unimpeded access of humanitarian organizations to IDPs. They should also ensure that IDPs can meet their basic 
needs (water, food, shelter, etc.) and access essential services (medical care, education, etc.).

\section{For other actors}

Recommendation 16: Other actors should ensure that requests for rapid and unimpeded access to IDPs by humanitarian organizations, as well as activities carried out pursuant to such access, be in full accordance with the principles of humanity, neutrality, impartiality and independence of humanitarian actors.

\section{Protection of IDPs}

\section{For States}

Recommendation 17: States should ensure that all relevant public authorities including armed and security forces - are fully informed of their obligations and instructed to facilitate freedom of movement and residence of IDPs.

Recommendation 18: Public authorities should develop adequate capacities at central and local levels to create and maintain an updated register of all IDPs. This can provide an agreed-upon baseline for all the actors concerned.

Recommendation 19: Public authorities should endeavour to allocate adequate efforts and resources to ensure that IDPs are able to obtain personal identity documents and other official documents within a reasonable time.

Recommendation 20: Public authorities should strengthen their laws, policies and concrete measures to ensure that the civilian and humanitarian character of IDP sites is maintained.

\section{For other actors}

Recommendation 21: International and humanitarian actors should provide coordinated support to States to ensure a practical and effective system to address family tracing and family reunification needs.

\section{Durable solutions for IDPs}

\section{For States}

Recommendation 22: States should ensure that all branches and agencies of the public authorities are fully informed of the need for meaningful consultation with and active engagement of IDPs and host communities in decision-making on durable solutions.

Recommendation 23: States should proactively initiate dialogue with international and national partners and donors on issues related to durable solutions in order to fulfil their own international obligations.

Recommendation 24: States (and other relevant stakeholders) should ensure that any peace agreement contains specific provisions and recommendations on 
addressing and solving existing situations of internal displacement, as necessary, taking into account the challenges of the context.

\section{For other actors}

Recommendation 25: The UN and other international actors that are in a position to do so should contribute to monitoring conditions of return, with particular attention to the perspectives and concerns of the IDP communities in question. They should also help ensure the voluntary and safe character of return and other durable solutions, as well as safety, dignity and adequate conditions for IDPs in their current places.

\section{Introduction}

\section{Background on internal displacement and the Kampala Convention}

The displacement of millions of people within their own countries, whether due to armed conflict or other situations of violence ${ }^{1}$ or natural disasters, became a pressing humanitarian concern in the second half of the twentieth century. As the number of IDPs has continued to grow in this new century, it has generated severe humanitarian, social and economic costs around the globe. In addition to reaching alarming proportions, internal displacement has become more protracted in nature. This reflects the increasing duration of armed conflicts and the inability to find lasting solutions for the hundreds of thousands of IDPs.

Africa is one of the continents most affected by this trend. In 2015, it was home to an estimated 12 million IDPs, that is, nearly a third of the total number of people displaced worldwide as a result of armed conflict and other violence. ${ }^{2}$ Displaced people often have particular needs and vulnerabilities, which may exacerbate the difficulties they face living in a conflict or violent environment. They are often deprived of their livelihoods and their assets. Families, particularly children, are often separated, and lose the safety and support that comes with living in their communities. Women and girls are especially vulnerable to sexual

1 "Other situations of violence" (hereafter "other violence") denotes "situations in which violence is perpetrated collectively but which are below the threshold of armed conflict. Such situations are characterized in particular by the fact that the violence is the work of one or several groups made up of a large number of people." International Review of the Red Cross (IRRC), Vol. 96, No. 893, February 2014, pp. 275-304: www.cambridge.org/core/journals/international-review-of-the-red-cross/article/theinternational-committee-of-the-red-crosss-icrcs-role-in-situations-of-violence-below-the-threshold-ofarmed-conflict/64183418A12D456A04D7BB59529547D5, consulted 1 October 2016.

2 Internal Displacement Monitoring Centre, GRID 2016: Global Report on Internal Displacement, IDMC, Geneva, 2016: www.internal-displacement.org/assets/publications/2016/2016-global-reportinternal-displacement-IDMC.pdf, consulted 2 October 2016. 
violence and exploitation. ${ }^{3}$ Poor access to essential goods and services, such as health care or education, is commonplace in displaced communities. IDPs may face exclusion due to a lack of documentation, voice or influence - or all three. Fear, anguish and uncertainty can dominate their lives.

In response to these urgent needs, African States joined forces to create the African Union Convention for the Protection and Assistance of Internally Displaced Persons in Africa (the Kampala Convention, or the Convention) in 2009.4 This pioneering treaty, ${ }^{5}$ the world's first ever legally binding instrument on internal displacement, entered into force in 2012 after 15 African States joined it. ${ }^{6}$ Today, 25 African States are party to the Kampala Convention, while another 18 have signed but are not yet party to it. ${ }^{7}$ While the number of States Parties has continued to grow, the momentum from earlier years has been lost.

A number of States have initiated or adopted domestic laws and policies to incorporate their obligations under the Convention. However, more action is needed. More concrete and practical measures are urgently required to realize the Kampala Convention's full potential and make a positive difference in the lives of IDPs on the continent. Above all, African States need to allocate greater resources-human, financial, technical and political-to preventing and responding to internal displacement.

The AU continues to play a central role in relation to the Kampala Convention. ${ }^{8}$ It has placed its commitment to the Convention at the centre of a

3 Norwegian Refugee Council, The Kampala Convention: Make it Work for Women, NRC, 2015, available at: (https://www.nrc.no/globalassets/pdf/reports/the-kampala-convention-make-it-work-for-women.pdf, consulted 8 October 2016.

4 African Union, African Union Convention for the Protection and Assistance of Internally Displaced Persons in Africa (Kampala Convention), AU, 2009: http://www.au.int/en/sites/default/files/treaties/7796-treaty0039_-_kampala_convention_african_union_convention_for_the_protection_and_assistance_of_internally_ displaced_persons_in_e.pdf, consulted 24 October 2016.

5 The Kampala Convention details the obligations not only of States, but also of non-State armed groups and international organizations with respect to preventing displacement and protecting and assisting IDPs. It also recognizes the vital role of host communities in responding to internal displacement. Furthermore, it takes into account the fact that internal displacement in Africa results from multiple causes, such as natural disasters, armed conflicts and development projects. For a review of these and other innovative aspects of the Convention, see Internal Displacement Monitoring Centre, From Kampala to Istanbul: Advancing Global Accountability for IDPs through Law and Policy Making, IDMC, Geneva, 19 May 2016: http://www.internal-displacement.org/search?q=From+Kampala+to +Istanbul, consulted 29 September 2016.

6 ICRC, "ICRC welcomes entry into force of Kampala Convention for displaced persons", Addis Ababa/ Geneva, 12 December 2012: https://www.icrc.org/eng/resources/documents/news-release/2012/12-05kampala-convention-entry-into-force.htm, consulted 29 September 2016.

7 African Union, List of Countries which Have Signed, Ratified/Acceded to the African Union Convention for the Protection and Assistance of Internally Displaced Persons in Africa (Kampala Convention), African Union, Addis Ababa, 1 April 2016: http://www.au.int/en/sites/default/files/treaties/7796-sl-african_ union_convention_for_the_protection_and_assistance_of_internally_displaced_persons_in_africa_kampala_ convention_11.pdf, consulted 29 September 2016.

8 Article 8(3) of the Kampala Convention attributes an important role to the AU in supporting States Parties to fulfil their obligations related to the protection and assistance of IDPs under the Convention. In turn, Article 5(3) of the Convention recognizes that States Parties have the obligation to respect the AU's mandate. 
broader humanitarian agenda..$^{9}$ Acknowledging the urgent need to address internal displacement on the continent and the Convention's potential to this effect, the AUC launched a strategy, in cooperation with its partners and UN agencies. This strategy aims at achieving continent-wide ratification and full implementation of the Convention. It focuses on four key elements: (1) capacity-building for Member State institutions dealing with the issue of internal displacement; (2) promoting ratification and domestication of the Kampala Convention; (3) strengthening and monitoring reporting mechanisms; and (4) awareness of, advocacy for and promotion of the Convention.

Promoting the Kampala Convention has also been a key priority for Chaloka Beyani, the outgoing UN special rapporteur on the human rights of internally displaced persons. Mr Beyani has argued strongly for the full operationalization of the Kampala Convention. By this, he means not only ratifying the Convention and passing legislation, but also implementing specific policies and practical measures that improve the situation for IDPs. ${ }^{10}$ His emphasis on operationalizing the Convention added further impetus to carrying out the stocktaking exercise.

\section{The ICRC and the stocktaking exercise}

The decision to carry out this stocktaking exercise on the Kampala Convention is part of the ICRC's commitment to tackling internal displacement worldwide. We believe the exercise is an important contribution to the ICRC's response to the growing humanitarian needs of IDPs. ${ }^{11}$ The ICRC's commitment to strengthen protection of people through law, operations and policy also finds its expression in this stocktaking exercise. ${ }^{12}$

The stocktaking exercise is also part of the ICRC's continued support to the Kampala Convention. The ICRC was involved from the outset in the drafting of the Kampala Convention, providing legal advice on issues relating to IHL and

9 The AU's Common African Position (CAP) provides a long-term strategic vision on addressing displacement and other humanitarian issues in Africa, in line with the AU's Agenda 2063. See African Union, Common African Position (CAP) on Humanitarian Effectiveness, AU, Istanbul, 23-24 May 2016: http://www.au.int/en/sites/default/files/newsevents/workingdocuments/29553-wd-cap_rev-final_ version_as_of_13_april_2016.pdf, consulted 29 September 2016. See also AU, Agenda 2063: The Africa We Want, 2nd ed., August 2014: http://archive.au.int/assets/images/agenda2063.pdf, consulted 2 October 2016.

10 See for example United Nations Human Rights Council, Report of the Special Rapporteur on the Human Rights of Internally Displaced Persons, Chaloka Beyani, United Nations, New York, 2014: http://www. refworld.org/docid/53999ed54.html, consulted 28 October 2016; and United Nations Human Rights Council, Report of the Special Rapporteur on the Human Rights of Internally Displaced Persons, Chaloka Beyani, United Nations, New York, April 2016, particularly paragraphs 37-43 and 101: http:// www.un.org/ga/search/view_doc.asp?symbol=A/HRC/32/35, consulted 28 October 2016. See also United Nations, Report of the Special Rapporteur on the Human Rights of Internally Displaced Persons, Chaloka Beyani, United Nations, New York, 2016: https:/documents-dds-ny.un.org/doc/UNDOC/ GEN/N16/246/93/PDF/N1624693.pdf?OpenElement, consulted 28 October 2016.

11 ICRC, ICRC Strategy 2015-2018, ICRC, Geneva, 2014, in particular p. 14, strategic objective 2.5: https:// shop.icrc.org/strategie-du-cicr-2015-2141.html, consulted 29 September 2016.

12 Ibid., p. 15. 
supporting the negotiation process that lead to its adoption in 2009. ${ }^{13}$ We later provided comments on the AU's draft Model Law for the Kampala Convention's implementation, especially on provisions drawn from IHL. ${ }^{14}$

Since 2009, the ICRC has been promoting the ratification of, or accession to, the Kampala Convention, and supporting its implementation. We do so by providing legal and technical advice on adopting and strengthening domestic legal frameworks to implement the Convention, and by recommending practical measures in dialogue with States across Africa. ${ }^{15}$

Specifically, the stocktaking exercise grew from the recognition of the importance of fostering States' exchanges of experiences in implementing the Kampala Convention. ${ }^{16}$ To date, many AU Member States have undertaken significant action to translate the Convention into reality, but they have tended to do so in isolation. There is a need to compile the diverse experiences of States in order to bolster efforts to go beyond implementation in theory and ensure operationalization in practice. The stocktaking exercise was designed to help in this regard. By collecting lessons learned and identifying examples of good practice, it offers an opportunity to share how the Kampala Convention can work best. This report aims to encourage further consideration and discussion - within and among States - on actions that can more effectively implement their obligations on internal displacement. Finally, the fruits of this exercise may help inspire States that have not yet ratified or acceded to the Convention to do so.

The ICRC is not new to this type of exercise. For many years, we have produced tools that provide technical support and guidance to States on implementing IHL ${ }^{17}$ and other legal frameworks domestically in relation to humanitarian issues, such as the protection of the provision of health care during armed conflict or other emergencies $^{18}$ and the plight of missing people and their families. ${ }^{19}$ The ICRC

13 The ICRC, along with the UNHCR, was specifically named in the preamble of the Kampala Convention, p. 3.

14 African Union, (Draft) Model Law for the implementation of the African Union Convention for the Protection and Assistance of Internally Displaced Persons in Africa, introduced at the Fifth Ordinary Session of the African Union Commission on International Law (AUCIL), 26 November - 5 December 2012, Addis Ababa, Ethiopia, AUCIL/Legal/Doc.6 (V), on file at the ICRC.

15 ICRC, Annual Report 2015, ICRC, Geneva, 9 May 2016: https://www.icrc.org/en/document/annualreport-2015-icrc, consulted 29 September 2016.

16 Internal Displacement Monitoring Centre et al., Workshop Report-Kampala Convention: From Ratification to Domestication and Operationalisation, IDMC, Geneva, April 2016: http://www.internaldisplacement.org/publications/2016/workshop-report-, consulted 29 September 2016.

17 See for example ICRC, The Domestic Implementation of International Humanitarian Law: A Manual, ICRC, Geneva, 1 December 2015: https://www.icrc.org/eng/resources/documents/publication/pdvd40. htm, consulted 29 September 2016.

18 Health Care in Danger project: http://healthcareindanger.org/hcid-project, consulted 2 October 2016. See also ICRC, "The implementation of rules protecting the provision of health care in armed conflicts and other emergencies: A guidance tool", 28 February 2015: https://www.icrc.org/en/document/ implementation-rules-protecting-provision-health-care-armed-conflicts-and-other-emergencies, consulted 21 October 2016.

19 ICRC, ICRC Report: The Missing and their Families, Geneva, 2003: https://www.icrc.org/eng/assets/files/ other/icrc_themissing_012003_en_10.pdf, consulted 24 October 2016. See also ICRC, Guiding Principles/Model Law on the Missing: https://www.icrc.org/en/document/guiding-principles-model-lawmissing-model-law, consulted 24 October 2016. 
capitalized on this expertise to carry out the stocktaking exercise. In addition, we were able to benefit from our presence in Africa, where our delegations in 29 countries carry out protection and assistance activities for IDPs, host communities and all those suffering the consequences of armed conflict or other violence. This has allowed the ICRC to add an operational perspective to considering how best to translate the Kampala Convention into practice. In doing so, the stocktaking exercise is intended to complement the valuable work of other actors, such as the UNHCR and the IDMC, that have provided particular support for the domestic implementation of the Kampala Convention.

\section{Methodology of the stocktaking exercise}

Throughout the first half of 2016, ICRC delegations across Africa provided updates and analysis on developments relating to IDPs, including States' latest actions to join, nationally implement and operationalize the Kampala Convention. This included States that are party to the Kampala Convention, whether or not they have adopted implementing laws and policies at the domestic level. It also includes some States that are not yet party to the Convention, but have adopted normative frameworks or policies on the protection of IDPs based on parallel provisions of the 1998 Guiding Principles on Internal Displacement (the Guiding Principles $)^{20}$ or of two of the Great Lakes Region protocols. ${ }^{21}$ Also included were some non-States Parties that have no domestic framework in place, but have taken some action to address internal displacement. Overall, the practice of 25 African countries was taken into account.

The decision to include the experience of States not party to the Kampala Convention allowed for the compilation of a broader set of African practice on key aspects of States' implementation of their obligations related to internal displacement. It also reflects an underlying recognition among States that the obligations of the Convention are built upon existing rules of IHL and IHRL, in addition to the Guiding Principles and the 2006 Great Lakes Pact. ${ }^{22}$ Although some States have not ratified the Convention, they may have adopted measures that result in concrete benefits for IDPs. Such practices can be a source of

20 United Nations, Guiding Principles on Internal Displacement, 11 February 1998: https://documents-ddsny.un.org/doc/UNDOC/GEN/G98/104/93/PDF/G9810493.pdf?OpenElement, consulted 28 October 2016.

21 International Conference on the Great Lakes Region, The Pact on Security, Stability and Development for the Great Lakes Region, Nairobi, 2006: http://www.icglr.org/images/Pact\%20ICGLR\%20Amended\% 2020122.pdf, consulted 24 October 2016. The Pact comprises 10 separate Protocols, including the Protocol on the Protection and Assistance to Internally Displaced Persons: http://www.refworld.org/ pdfid/52384fe44.pdf, consulted 10 October 2016, and the Protocol on the Property Rights of Returning Persons: https://www.lse.ac.uk/collections/law/projects/greatlakes/4.\%20Humanitarian\%20and\%20Social \%20Issues/4c.\%20Protocols/Final\%20protocol.PropertyRights\%20-En\%20r.pdf, consulted 8 October 2016. For comparison of the different provisions, see the Annex to this report.

22 See for example International Refugee Rights Initiative, Comparison of the Kampala Convention and the IDP Protocol of the Great Lakes Pact: A Briefing Note by the International Refugee Rights Initiative, January 2014: http://www.refugee-rights.org/Assets/PDFs/2014/Comparative\%20Note\%20on\%20the\%20Kampala \%20Convention\%20and\%20IDP\%20Protocol\%20FINAL-EN.pdf, consulted 29 September 2016. 
inspiration to States that have yet to ratify the Convention, as well as those States Parties that are experiencing challenges in implementing it. Finally, by identifying the experiences of States not party to the Convention, the exercise highlights the consideration that these States have given to putting into practice activities aimed at protecting and assisting IDPs. This helps illustrate to these States that, while they have yet to ratify the Convention, they are de facto already implementing components of it.

An independent consultant commissioned by the ICRC compiled and analysed the input received from delegations. The exercise consisted of the following:

1. An assessment of how the Kampala Convention is being implemented in domestic law and policy. This part sought to identify domestic normative and policy frameworks, whether specifically related to the Kampala Convention or not, that could have a concrete impact on the protection of and assistance to IDPs.

2. A review of practical measures and concrete actions adopted by States to implement the Convention.

In the analysis of State practice, the following questions were kept in mind:

- What impact does the Kampala Convention have on the ground?

- What difference can it make in the lives of IDPs?

- What more needs to be done - by States, the AUC, RECs and RMs, the ICRC and other organizations and humanitarian actors - for the full implementation of the Kampala Convention to become a reality?

In consultation with the ICRC's own experts and selected external experts, and building on further research, the analysis of the information compiled through the exercise led to the drafting of Findings (in the form of lessons learned, some examples of good practices and key challenges) and Recommendations.

The Findings reflect the current level of States' efforts to prevent and address internal displacement. As part of the Findings, the examples of good practices reflect the experiences of States that have successfully adopted normative, policy or concrete measures to implement the Convention's obligations. The mention of specific States in relation to good practices is made so that other States can study those experiences and consult the relevant laws, policies and practices as needed. It is not intended to exclude other States that may have taken equally important actions. In addition, referring to legislation or policies as good practices does not necessarily mean that they are being fully implemented in practice; in some cases implementation needs more time.

The Recommendations are based upon the Findings but look ahead, suggesting actions to address challenges in implementing the Convention and offering insight as to how current implementation of the Convention can be strengthened. These Recommendations are all, it should be emphasized, without prejudice to the duty of States to carry out their respective obligations under international and domestic law. 
As part of the stocktaking process, the ICRC convened a consultation meeting at the AU headquarters in Addis Ababa, Ethiopia, on 14 September 2016. Prior to this, the preliminary findings and draft recommendations from the exercise had been shared with the AUC and its Member States. Representatives of more than 25 Member States, the AUC's Department of Political Affairs and several RECs/RMs attended the meeting. Working under the Chatham House Rule, ${ }^{23}$ they provided feedback on the stocktaking exercise and its initial conclusions, and exchanged views on the way forward. The outcomes of this meeting contributed to the finalization of the Findings and Recommendations that form the heart of this report.

At the same time as the stocktaking exercise was being carried out, the ICRC's delegation in Abuja was working on an in-depth country report, looking at the operationalization of the Kampala Convention in the states of Borno, Adamawa and Yobe in Nigeria. The resulting report is based on assessments carried out over the last year, including a survey of IDPs in the three states and interviews with key government and non-government stakeholders involved in providing assistance and protection to IDPs. It will be published in the coming months.

\section{Structure and scope of this report}

The main substance of the report consists of more than 85 Findings and 25 Recommendations. These are organized in five parts. Each part is based on a set of key obligations under the Kampala Convention grouped by topic, as follows:

1. Prevention

2. Planning, management and monitoring of protection and assistance activities

3. Providing adequate humanitarian assistance to IDPs

4. Protection of IDPs

5. Durable solutions for IDPs

Each of the 25 Recommendations is followed by a supporting rationale. The Recommendations are mainly intended for States, but in each of the five parts, one or more Recommendations also concern other actors. These may include the AUC, RECs, RMs, the UN, the ICRC and civil society organizations.

Given the wide range of topics covered in the Kampala Convention, we found it necessary to limit the scope of the exercise. This report, therefore, does not purport to be exhaustive. It is focused on those obligations most familiar to the ICRC, either because they are drawn directly from IHL or because they relate to humanitarian concerns that we encounter in our operations across Africa (e.g. issues of IDP registration and documentation).

23 Participants are free to use the information received at the event, but neither the identity nor the affiliation of the speakers and panellists, nor that of any other participant, may be revealed: http://www. chathamhouse.org/about/chatham-house-rule, consulted 21 October 2016. 
In addition, the report's focus on States meant it was not possible to examine the obligations of NSAGs, defined as "armed groups" and "non-State actors" in the Kampala Convention. ${ }^{24}$ These obligations were clearly considered important by Member States when negotiating and adopting the Convention, and remain so today.

Finally, not all of the observations made and conclusions drawn by the ICRC through the stocktaking exercise are included in the report. Some of these will be shared directly with the States concerned in the ICRC's traditional framework of bilateral confidential dialogue that we maintain with public authorities around the globe.

\section{Findings and recommendations}

\section{Prevention}

\section{Summary of key obligations}

(a) Incorporate obligations under the Kampala Convention in domestic law (Article 3.2(a));

(b) Ensure individual criminal responsibility for arbitrary displacement (Article 3.1(g)).

\section{Lessons learned}

The lessons learned in the areas of ratification or accession and incorporation in domestic law are perhaps predictable for any public officials or other experts who have worked on treaty domestication, but are nonetheless important.

First and foremost, experience across Africa confirms that it is crucial for States to take action on ratification or accession and domestic implementation of the Kampala Convention before a crisis occurs that would result in internal displacement. Regardless of the causes of internal displacement in a given situation, it is rare that it develops slowly enough to allow policy makers and lawmakers to respond in real time by putting appropriate laws and policies in place.

With this in mind, States may find it useful to initiate their own review on how they could revive or expedite the procedures required in their particular jurisdiction to join the Convention and implement it at the national level. In particular, they may wish to follow the example of the numerous States that have taken advantage of the technical support available to expedite their ratification or accession and national implementation processes. In this regard, one very useful starting point is the AUC, which developed a draft Model Law and has already advised a number of States on its application. International organizations such as the IDMC, NRC and UNHCR organise training for public officials, without 
charge, on the national implementation of the Kampala Convention, and support States in adopting laws and policies on internal displacement. ${ }^{25}$ In June 2015, the GPC, led by the UNHCR, established a TTLP as a technical entity to coordinate global efforts on law and policy-making on internal displacement. As part of its activities, the TTLP organizes learning and technical support opportunities to strengthen States' capacity to develop and implement national IDP legislation and policies. ${ }^{26}$ For its part, the ICRC's Advisory Service on IHL has produced a series of tools and publications providing technical support and guidance on adopting national legislation, as well as analysis of State practice to address humanitarian issues. ${ }^{27}$ The ICRC also provides, on a regular basis, confidential advice to the authorities on developing domestic normative and policy frameworks that reflect Kampala Convention obligations.

It is evident that States will achieve the best results where there is a clear and sustained political will to discharge their responsibilities. This is the case both in incorporating the Kampala Convention into domestic law, and in preventing and responding to internal displacement. Officials with responsibilities for IDP-related matters would be well advised to consider anew how they might build ownership and momentum in their own country towards becoming party to the Convention and especially to its implementation.

One important lesson learned from the ICRC's field consultations and many years of work on behalf of IDPs in Africa, is that the domestic implementation of the Kampala Convention requires an inclusive process. This means engaging all key domestic actors in consultations, information sharing and decision-making. These include ministries and governmental agencies concerned, at central and field levels, municipal authorities and civil society organizations, as

25 For example, see Internal Displacement Monitoring Centre, A Review of the Normative Framework in Kenya relating to the Protection of IDPs, IDMC, Geneva, August 2015: www.internal-displacement.org/ publications/2015/a-review-of-the-normative-framework-in-Kenya, consulted 29 September 2016; Internal Displacement Monitoring Centre, Applying the Kampala Convention in the Context of Zimbabwe, IDMC, Geneva, February 2015: www.internal-displacement.org/publications/2015/applyingthe-kampala-convention-in-the-context-of-zimbabwe, consulted 30 September 2016; Internal Displacement Monitoring Centre, Workshop Report-Domesticating the Kampala Convention: Law and Policy Making, IDMC, Geneva, 2014, available at: www.internal-displacement.org/assets/publications/2014/201407-afkampala-convention-law-policy-workshop-report-en.pdf, consulted 25 October 2016 (on supporting Liberia's national process of ratification and implementation of the Kampala Convention). See also Internal Displacement Monitoring Centre, Workshop Report-The National Responsibility to Protect Internally Displaced Persons: The Kampala Convention, IDMC, Geneva, May 2015: www.internaldisplacement.org/publications/2015/the-national-responsibility-to-protect-internally-displaced-people-thekampala-convention, consulted 28 October 2016.

26 The ICRC takes part in meetings of the TTLP as active observer and has supported various initiatives by the TTLP since its creation, including with regard to the promotion and implementation of the Kampala Convention. For example, the ICRC was a facilitator in the TTLP-sponsored regional workshop on the national implementation of the Kampala Convention, organized by the AU in partnership with the NRC and the UNHCR in Addis Ababa, Ethiopia, at the end of 2015. The workshop brought together six AU Member States with the purpose of supporting the domestication and implementation of the Kampala Convention, while promoting national responsibility and the sharing of experiences between them. See Internal Displacement Monitoring Centre, Workshop Report-Kampala Convention: From Ratification to Domestication and Operationalization, op. cit.

27 For more information on these tools, see: www.icrc.org/en/war-and-law/ihl-domestic-law/ documentation\#penal, consulted 29 September 2016. 
well as IDPs and host communities. ${ }^{28}$ Without an inclusive process, the necessary ownership by these actors will likely be lacking. This could potentially result in delays at one or more points in the domestic implementation process.

Public education and raising awareness of the Kampala Convention and the plight of IDPs are important factors in translating political commitments into concrete measures. These activities can be usefully carried out with the public authorities and civil society, as well as with IDPs and host communities. They can serve to encourage the public's interest and engagement, and their dialogue with public authorities, on the issue of internal displacement. This in turn can help ensure that addressing internal displacement remains a priority that enjoys sustained political will. ${ }^{29}$ Special attention should be given to ensuring that draft or adopted laws and policies are made available in all official languages and, if different, in the languages of the most affected stakeholders, whether IDP or host communities.

It is crucial that laws and policies on internal displacement contain provisions for adequate means (institutional/mandate, human resources, budget) for their implementation and operationalization. This has been an important and sometimes difficult "lesson learned" in numerous places, where implementation processes have been initiated with serious effort, but have stalled because of a lack of adequate resources to sustain the work. Often this failure to ensure sufficient resources has been to the detriment of the specific protection and assistance needs of IDPs.

Finally, strong and clear criminal prohibitions relating to displacement can have an important deterrent effect and can contribute to broader efforts to combat impunity for violations of IHL. For decades, the ICRC has worked closely with States in developing tools and resources to support domestication of IHL obligations, including on criminal responsibility and on mechanisms for coordination among public authorities to strengthen prevention of and accountability for serious violations of IHL. ${ }^{30}$

28 On the importance of a consultative approach in adopting national instruments on IDPs, see Global Protection Cluster, Regulatory Frameworks on Internal Displacement: Global, Regional and National Developments, 2016, p. 20: http://reliefweb.int/sites/reliefweb.int/files/resources/UNHCR-GPC-RegFramework-IDP.pdf, consulted 29 October 2016. On the process of developing domestic legislation and policies, see Internal Displacement Monitoring Centre and Brookings-LSE Project on Internal Displacement, National Instruments on Internal Displacement: A Guide to their Development, August 2013: www.internal-displacement.org/publications/2013/national-instruments-on-internaldisplacement-a-guide-to-their-development, consulted 31 October 2016.

29 On engaging parliamentarians in advocacy and awareness-raising efforts to support the adoption of national legal instruments on IDPs, in view of the important role parliamentarians can play in promoting such instruments, see United Nations High Commissioner for Refugees and InterParliamentary Union, Internal Displacement: Responsibility and Action - Handbook for Parliamentarians, UNHCR \& IPU, Geneva, 2013: www.unhcr.org/protection/migration/525bee0c9/inter-parliamentaryunion-ipu-handbook-internal-displacement-responsibility.html, consulted 31 October 2016.

30 See the penal repression factsheets from the ICRC's Advisory Service on IHL: www.icrc.org/en/war-andlaw/ihl-domestic-law/documentation\#penal, consulted 2 October 2016; ICRC, Advisory Service on IHL, Preventing and Repressing International Crimes: Towards an "Integrated" Approach Based on Domestic Practice: Report of the Third Universal Meeting of National Committees for the Implementation of International Humanitarian Law, ICRC, Geneva, 29 August 2013: www.icrc.org/en/publication/4138preventing-and-repressing-international-crimes-towards-integrated-approach-based, consulted 2 October 2016. 


\section{Some examples of good practices}

Across Africa, States have taken a range of actions to realise the national implementation of the Kampala Convention ${ }^{31}$ and to more broadly develop a national approach to IDP-related challenges. While there is, of course, no single "template" or one single "best" approach, the number and diversity of efforts undertaken provide practical examples for other States, as they move to join and/ or implement the Convention in their own particular context.

Uganda was a pioneer, adopting The National Policy for Internally Displaced Persons in 2004, ${ }^{32}$ long before the Kampala Convention was created. Uganda's policy was designed to implement the Guiding Principles, and is broad in scope. It includes the establishment of a national coordination body, detailed arrangements for intergovernmental coordination at the national and the local levels, specific provisions for aspects of protection and assistance, and arrangements for public education. ${ }^{33}$ The Policy's implementation was the subject of a multi-stakeholder review in 2006. The report on this review provides a helpful snapshot, detailing the challenges of implementation, and remains valuable a decade later. ${ }^{34}$

In Somalia and Mali, the authorities have worked closely with international partners to develop national laws and policies. ${ }^{35}$ This widened the scope of

31 Internal Displacement Monitoring Centre, The Kampala Convention Two Years On: Time to Turn Theory into Practice, IDMC, Geneva, December 2014: www.internal-displacement.org/publications/2014/thekampala-convention-two-years-on-time-to-turn-theory-into-practice, consulted 29 September 2016.

32 Republic of Uganda, Office of the Prime Minister, Department of Disaster Preparedness and Refugees, The National Policy for Internally Displaced Persons, Uganda, August 2004: www.brookings.edu/wp-content/ uploads/2016/07/Uganda_IDPpolicy_2004.pdf, consulted 29 September 2016.

33 For a good summary of Uganda's National Policy for IDPs see J. Miller, "Brookings-Bern Project on Internal Displacement: Uganda's IDP Policy", Forced Migration Review, January 2007: www.brookings. edu/wp-content/uploads/2016/06/200701_JM_FMRUganda.pdf, consulted 29 September 2016.

34 For more information on the practical implementation of Uganda's National Policy, see the summary of the 2006 workshop: Universität Bern and the Republic of Uganda, Workshop on the Implementation of Uganda's National Policy for Internally Displaced Persons, Kampala, Uganda, 3-4 July 2006: www. brookings.edu/wp-content/uploads/2016/06/Uganda_Workshop2006_rpt.pdf, consulted 29 September 2016. For additional background on other early efforts to establish national laws and strategies on internal displacement, especially in relation to the Guiding Principles, see: J. Wyndham, A Developing Trend: Laws and Policies on Internal Displacement, Human Rights Brief, Vol. 14, Issue 1, Article 2, 2006: http://digitalcommons.wcl.american.edu/cgi/viewcontent.cgi?article=1191\&context=hrbrief, consulted 29 September 2016.

35 A signatory since 23 October 2009, Somalia has not yet ratified the Convention. It has developed, but not yet adopted, a comprehensive national policy on internal displacement under the leadership of the Ministry of Interior and Federalism, with the help of the Office of the UN Special Rapporteur on the Human Rights of IDPs. In addition, authorities in Puntland developed policy guidelines on displacement in 2012, and in 2016 the Somaliland Internal Displacement Policy was adopted at the initiative of the Ministry of Resettlement, Rehabilitation and Reconstruction, with the assistance of various international organizations, including the local protection cluster. For more information on the efforts to develop and implement a national policy in Somalia, see: J. Drumtra, Brookings-LSE Project on Internal Displacement, Internal Displacement in Somalia, Washington, December 2014, pp. 16-19: www.refworld.org/docid/54bd197b4.html, consulted 8 October 2016; Global Protection Cluster, Regulatory Frameworks on Internal Displacement, op. cit., p. 24. In Mali, a party to the Convention since 2012, an inter-institutional committee for the domestication of the Kampala Convention was established in April 2016 by the Ministry of Solidarity, Humanitarian Action and Reconstruction in the 
consultation amongst these key groups and is expected to bear fruit as those States move forward with finalizing and bringing into force their policies and programmes.

In Kenya, a comprehensive framework to address displacement issues has been developed and adopted. ${ }^{36}$ Kenya is a party to the Great Lakes Pact, but not yet a party to the Kampala Convention. It is worth noting that Kenya's framework addresses a number of Convention obligations and can serve as an example for other States, party and non-party alike. ${ }^{37}$

In Burundi, a comprehensive peace agreement (the Arusha Peace and Reconciliation Agreement for Burundi, 2000) includes multiple provisions relating to internal displacement (e.g. on access to people in need and the security of international personnel and provision of humanitarian aid) that are consistent with the Kampala Convention..$^{38}$ Burundi is not yet a party to the Kampala Convention, but here again these measures are, in many cases, consistent with Convention obligations.

In the Democratic Republic of the Congo, the Child Protection Code (2009) includes a provision on the rights of displaced children, which specifies their right to protection and humanitarian assistance. ${ }^{39}$ This is an interesting example of a legal basis for protecting and assisting IDP children, even in the absence of specific legislation implementing the Kampala Convention.

Also in the Democratic Republic of the Congo, the authorities have initiated a working group to convene representatives of humanitarian and UN agencies and have been consulting national stakeholders on the terms of reference for this body (Groupe de travail technique sur le déplacement). Such a structure and process is likely to boost consultation and engagement by key stakeholders, who can be expected to contribute more to national action on internal displacement in the future. ${ }^{40}$

North. Charged with steering the policy-making process, the committee initiated a normative audit of the Malian legal framework in light of the requirements of the Kampala Convention. Republic of Mali, Décision No. 2016/0109 du Ministre de la Solidarité, de l'Action Humanitaire et de la Reconstruction du Nord, 28 April 2016, on file at the ICRC.

36 Internal Displacement Monitoring Centre, Towards a Comprehensive Response to Internal Displacement in Kenya: A Roadmap for Action, IDMC, Geneva, August 2015: www.internal-displacement.org/ publications/2015/towards-a-comprehensive-response-to-internal-displacement-in-kenya-a-roadmapfor-action, consulted 29 September 2016. See also Refugee Consortium of Kenya and the Danish Refugee Council, Behind the Scenes: Lessons Learnt from Developing a National Policy Framework on Internal Displacement in Kenya, January 2013: https://goo.gl/B45dsu, consulted 31 October 2016.

37 Internal Displacement Monitoring Centre, A Review of the Normative Framework in Kenya relating to the Protection of IDPs, op. cit.

38 Arusha Peace and Reconciliation Agreement for Burundi, Arusha, August 2000, for example, Protocol IV, Chapter 1, Articles 1-3: https://peaceaccords.nd.edu/accord/arusha-peace-and-reconciliation-agreementburundi, consulted 24 October 2016.

39 Democratic Republic of the Congo, Loi No. 09/001 du 10 janvier 2009 Portant sur la Protection de l'Enfant, Article 2(2) : www.leganet.cd/Legislation/JO/2009/L.09.001.10.01.09.htm\#TICI, consulted 10 October 2016.

40 For background on the challenges of internal displacement in the Democratic Republic of the Congo and responses to these, see: Internal Displacement Monitoring Centre, Democratic Republic of the Congo 2014: Multiple Crises Hamper Prospects for Durable Solutions, IDMC, Geneva, December 2014: www.internaldisplacement.org/sub-saharan-africa/democratic-republic-of-the-congo/2014/multiple-crises-hamperprospects-for-durable-solutions, consulted 8 October 2016. 
In many States, existing domestic laws provide for the criminalization of acts of arbitrary or forced displacement. In Rwanda, to give but one example, the Penal Code (2012) includes crimes and penalties relating to arbitrary displacement. $^{41}$ Of note, the criminal law provisions in Rwanda are complemented by separate measures that address other aspects related to the prevention of displacement. ${ }^{42}$ Several African States have criminalized forced displacement in their implementing legislations of the Geneva Conventions or the Statute of the International Criminal Court (e.g. Botswana, Burkina Faso, Kenya, Mauritius, Nigeria and Senegal). It is worth mentioning that Burkina Faso, Mauritius and Senegal have criminalized forced displacement as a crime against humanity and a war crime for both international and non-international armed conflicts. ${ }^{43}$

In West Africa, States have taken action through the ECOWAS to promote awareness of and adhesion to the Convention, including through a tour of select capitals in 2016. In East Africa, States joined forces under the auspices of the IGAD in October 2016 at a seminar in Nairobi, jointly organized with the ICRC. The seminar reviewed national measures undertaken by IGAD Member States and considered how to promote the Convention. ${ }^{44}$

These represent only a sample of the kinds of actions undertaken by States. Considered together, they demonstrate that there are many examples of States having overcome a range of challenges regarding national implementation. Considered on their own, they demonstrate that there are many recent, practical precedents for States that are now-or soon will

41 The 2012 Penal Code provides in Article 123(7) that forced displacement of the civilian population or their transfer to or systematic detention in concentration or forced labour camps is a war crime. Penalties are provided for under Article 125. See Republic of Rwanda, Organic Law No. 01/2012/OL of 02/05/2012 Instituting the Penal Code: www.unodc.org/cld//document/rwa/2012/penal_code_of_rwanda.html?lng= en, consulted 25 October 2016.

42 For example, the 2009 National Disaster Management Policy (revised in 2012) refers to "mass movement of population", which includes internal displacement, as a "main hazard" in Rwanda: www.google.com/ url?sa=t\&rct=j\&q=\&esrc=s\&source=web\&cd=1\&ved=0ahUKEwiEloXJgK_PAhVRGsAKHb-EAQ8QF ggdMAA\&url=http://\%3A\%2\%F\%2Fwww.ifrc.org\%2Fdocs\%2FIDRL\%2FRwandaDisaster_Management_ Policy_01.pdf\&usg=AFQjCNHs1Pf4cgXS4XuekwnaEKdvv63BhA\&cad=rja, consulted 10 October 2016. See also Republic of Rwanda, Law No. 41/2015 of 29/08/2015 relating to Disaster Management, available at: www.rema.gov.rw/fileadmin/templates/Documents/rema_doc/Laws\%20updated/Law_establishing the_Gishwati_-Mukura_National_Park.pdf, consulted 10 October 2016. This new law refers to the Kampala Convention in its preamble. While it does not refer to displacement directly, internal displacement could qualify as a disaster, according to the definition of disaster in Article 2(4) of the law: "serious calamity occurring on a small or large area of the country involving loss of life, physical or psychological injury or important material, economic, or environmental damages, which exceeds the ability of the affected population to overcome with its own resources".

43 For more information, see the ICRC National Implementation Database: https://ihl-databases.icrc.org/ applic/ihl/ihl-nat.nsf/vwLawsByCountry.xsp, consulted 28 October 2016.

44 The preliminary findings of the ICRC stocktaking exercise were also shared with participants during the IGAD-ICRC seminar, including a number of examples of good practices from East African States. See "Kenya: IGAD and ICRC hold seminar on the Kampala Convention", 10 October 2016: www.icrc.org/ en/document/igad-and-icrc-hold-seminar-kampala-convention, consulted 24 October 2016. 
be - taking specific steps to make the Kampala Convention an integral part of their domestic law.

\section{Key challenges}

The momentum the Kampala Convention enjoyed between its adoption in 2009 and its entry into force in 2012 has stalled in recent years.

Few States have ratified or acceded to the Convention in the period from 2014 to the present. As of September 2016, there were 18 AU Member States that had signed up to the Kampala Convention, but had not taken the required action to ratify or accede to it, even after several years. ${ }^{45}$

Of equal concern is that many States are experiencing delays in the process of enacting the necessary legislation to give domestic effect to the Convention. In some cases, these delays exceed several years. Causes for this vary from State to State. They may include: a lack of awareness by some authorities on the issue of internal displacement, their obligations and/or on the importance of the Kampala Convention; lack of capacity; lack of budget allocations; internal displacement not being seen as a priority issue by the authorities; and the involvement of the State in an armed conflict. Similarly, a number of States have invested considerable time and effort into elaborating a national IDP policy or strategy, but have not managed to complete this process.

Numerous States in the monist legal tradition rely on their constitution, which automatically transposes international treaties into domestic law. ${ }^{46}$ However, this generally does not complete domestic implementation. For example, the provisions of the Kampala Convention concerning criminal responsibility will likely be unenforceable or contrary to the principle of legality, unless there are designated penalties in law.

In practice, there are few or no prosecutions relating to crimes under the Kampala Convention taking place in domestic courts today. The lack of specific criminal provisions in domestic legal orders is certainly one of the main factors that underlie the lack of operationalization of this part of the Convention.

When an armed conflict is ongoing, measures can and, in many cases, must be taken by States and other parties to the conflict to prevent displacement from occurring in the first place. This is especially true in ensuring respect for IHL and increasing efforts to protect civilians and limit the harm to which they can be exposed. In practice, violations of IHL continue to be a major cause of internal displacement in armed conflicts in Africa. The challenge here is to strengthen States' commitment (and capacity) to respect and ensure respect for IHL. Another challenge, particularly in protracted armed conflicts, is to avoid

45 African Union, List of Countries which Have Signed, Ratified/Acceded to the African Union Convention for the Protection and Assistance of Internally Displaced Persons in Africa (Kampala Convention), op.cit.

46 For a discussion of the monist legal tradition and implications for implementation of IHL treaties, see ICRC, The Domestic Implementation of International Humanitarian Law: A Manual, ICRC, Geneva, September 2015: www.icrc.org/eng/assets/files/publications/icrc-002-4028.pdf, consulted 29 September 2016. 


\section{(4) Kampala Convention ICRC Status of signature and ratification}

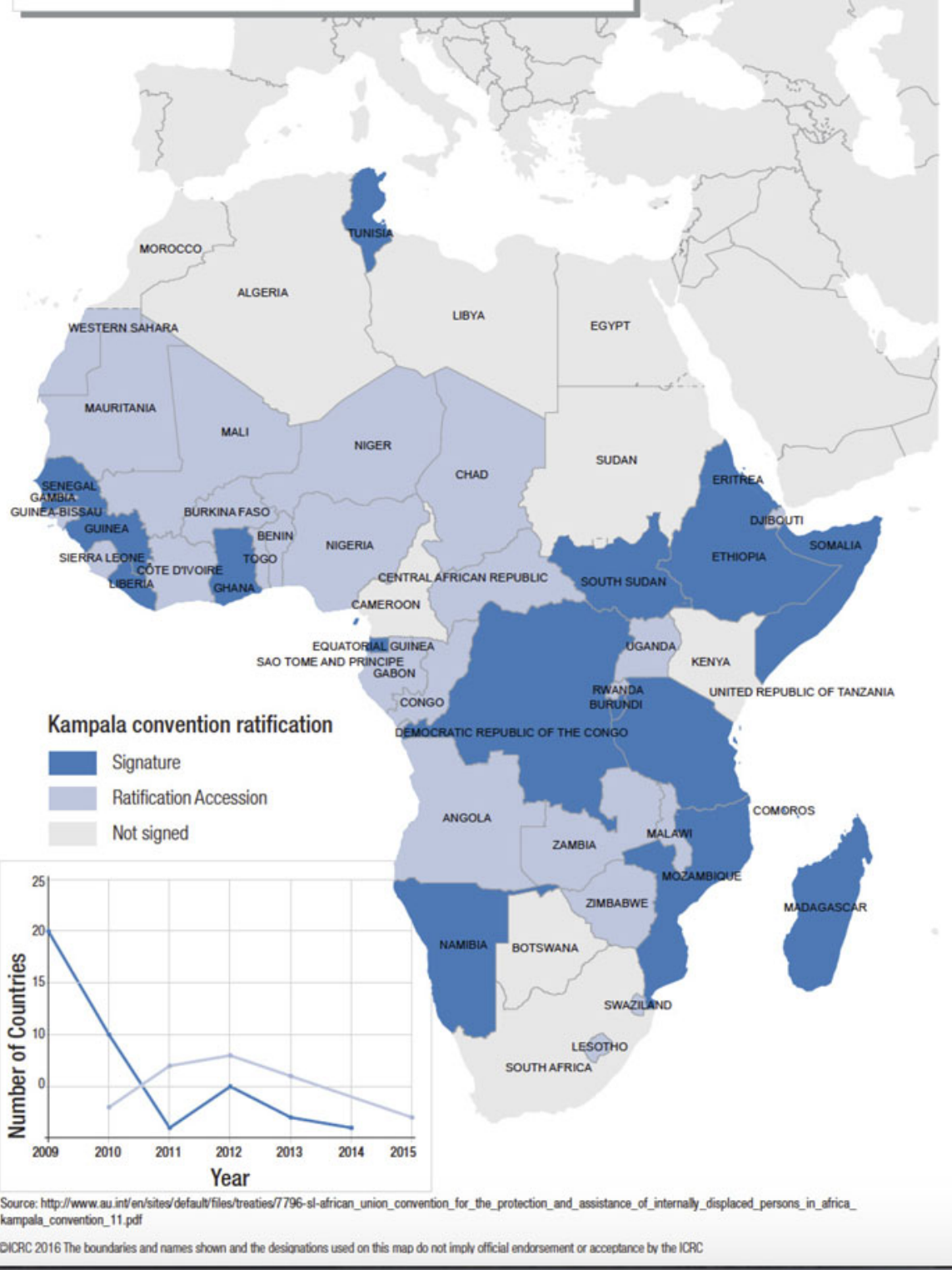




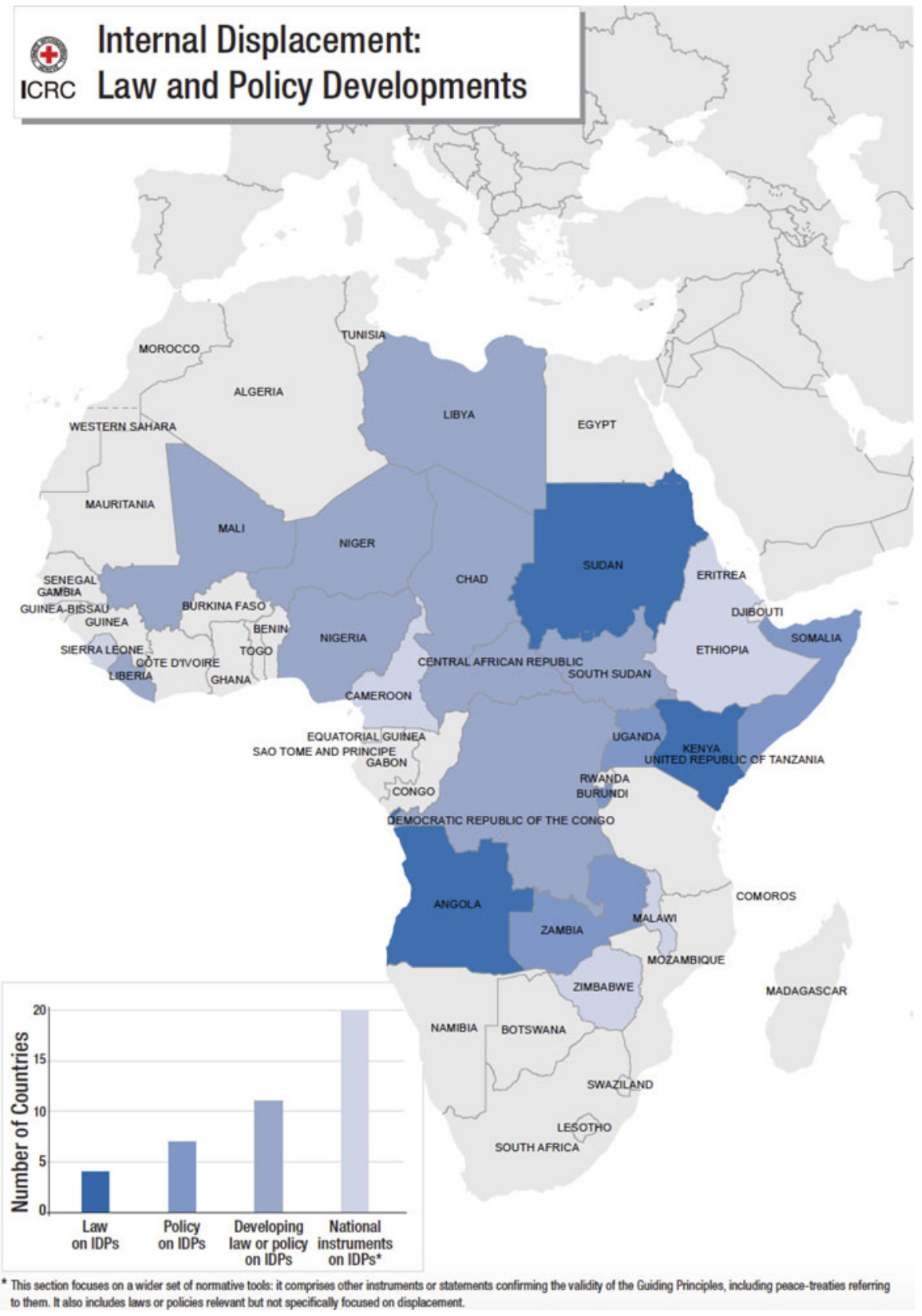


displacement that can be seen by parties as a natural incidence of military operations, and whose rationale in this regard is not being questioned.

State authorities may find it difficult to prevent displacement in areas where NSAGs are present. There is no simple solution to this obstacle, which can have serious and protracted humanitarian consequences. That said, it must be recalled that the Kampala Convention creates obligations for NSAGs (referred to as "Armed Groups" and "Non-state actors" in the Convention) ${ }^{47}$ and includes numerous references to them. ${ }^{48}$ More generally, IHL establishes obligations on NSAGs that are party to an armed conflict. ${ }^{49}$

\section{Recommendations}

\section{For States}

Recommendation 1: States that have not yet done so should expedite their ratification of, or accession to, the Kampala Convention.

- The Kampala Convention offers a comprehensive and detailed framework of reference that can guide States in discharging their sovereign obligations in preventing and responding to internal displacement. Thus, ratification of the Convention provides a State with a clear legal basis for the adoption of domestic normative and policy measures related to the protection and assistance of IDPs.

- There are a number of States that have not ratified the Kampala Convention but have been putting in place concrete measures that correspond to obligations under the Convention. For such States, ratification is a logical step that would bring coherence to domestic law, policy and practice, and is a further exercise of their sovereignty.

- Numerous obligations contained in the Kampala Convention are already included in the existing obligations of States under IHL and IHRL. Ratification of the Kampala Convention complements and builds upon those existing legal obligations, providing more clarity on how they should be interpreted and implemented. This can help States reinforce the protection of and assistance to IDPs.

- Ratification of the Kampala Convention demonstrates a State's commitment to preventing and addressing internal displacement. This can help attract donor support and technical advice/assistance for the full range of Kampala Convention elements. This can include technical advice/assistance on

47 Kampala Convention, Article 1(e) and 1(n) respectively.

48 Ibid. See for example, Articles 2(e), 3(1)(h) and (i), and 7(4) and (5).

49 As noted in the Introduction above, this report is focused on the obligations and practice of States, thus it does not examine the obligations of NSAGs, which are recognized as an essential component of the Kampala Convention. 
adopting domestic legislation and coordination structures and financial support to assist IDPs and host communities in the emergency phase and in the longer term.

- Additional ratifications reinforce the Kampala Convention's legitimacy and relevance by highlighting the AU's leading role in responding to the challenge of internal displacement. They also lead to more experiences and good practices that can be shared with other States in Africa and beyond.

Recommendation 2: States party to the Kampala Convention should initiate and complete actions to incorporate treaty obligations in domestic law and policy processes, including criminal prohibitions, requesting advice and technical support if/as needed.

- Ratification is an important step. However, it needs to be followed by the adoption of normative, policy and concrete measures at the national level in order to ensure that the protections afforded by the Kampala Convention become a reality for IDPs.

- Domestic implementation through measures appropriate for a State Party's legal system and governance structures will help ensure that the State is able to respond effectively to the needs of IDPs.

- To be effective, laws and policies developed to implement the Kampala Convention need to include the provisions for adequate means (institutional/ mandate, human resources, budget) for their practical implementation.

- States can request advice and technical assistance on domestic implementation from the AUC (which has developed a draft Model Law), other States party to the Kampala Convention and from various international and humanitarian organizations (such as the ICRC and the UNHCR). They can also benefit from the growing set of good practices and lessons learned on the implementation of the Kampala Convention. In so doing, domestic implementation helps expand the expertise of public authorities on matters related to internal displacement. In addition, by taking inspiration from the experience of other States and adapting solutions to their specific contexts, States can in turn contribute to establishing good practices.

- Criminalizing arbitrary displacement that amounts to a war crime or a crime against humanity is a legal obligation for all States party to the Convention. Strengthening the domestic legal framework on this aspect will allow States Parties to ensure individual criminal responsibility for perpetrators in domestic courts.

- Domestic implementation measures demonstrate a State's readiness to effectively discharge its primary responsibility for IDPs on its territory. This can help attract donor support and technical advice and assistance. States can maintain this support by demonstrating the effectiveness of their domestic strategies and mechanisms. 
Recommendation 3: States should take steps to promote knowledge of the Kampala Convention for all the actors concerned, including IDPs themselves, host communities, civil society and public authorities, at central, regional and local levels. (See also Recommendation 6 on the role of other actors in awareness-raising and capacity-building and Recommendation 12 on the importance of fostering national ownership through capacity-building activities.)

- This is an essential element to ensure an inclusive national process from ratification through domestication and practical implementation of the Convention. Public awareness contributes to ownership and sustainability of such a process by strengthening the commitment of all the actors involved to fully implementing the Convention.

- International and humanitarian partners will often be ready and willing to cooperate with States on awareness-raising activities, as well as to carry out more specialized capacity-building activities for public authorities and other actors, in particular public officials.

- In the same vein, local civil society actors are often well placed to promote knowledge of the Convention. In many cases, their capacities can be used to complement efforts by public authorities and their partners. Notably, the efforts of civil society actors can help public authorities to better understand and build upon public interest on IDP-related matters and the Kampala Convention in particular. They can also help ensure sustained interest in domesticating the Convention.

- Of great importance are activities to raise awareness of the Kampala Convention among IDP communities themselves. These activities can empower IDPs by making them more aware of their rights and responsibilities.

Recommendation 4: States should ensure that all relevant public authorities including armed and security forces - are fully informed of their obligations and instructed to respect and ensure respect for IHL.

- Violations of IHL are a major cause of displacement during armed conflict.

- Improving respect for IHL in armed conflicts will, in many cases, prevent displacement from occurring in the first place, by strengthening the protection of civilians and limiting the effects of hostilities on civilian lives and property.

- Of particular importance is respect for the fundamental principles of distinction, proportionality and precaution, as well as the prohibition on the forced displacement of the civilian population, in whole or in part, for reasons 
related to the armed conflict, unless the security of the civilians involved or imperative military reasons so demand..$^{50}$

- When displacement does occur, respect for IHL can help ensure that it is, as much as possible, kept to a minimum and is temporary. Furthermore, IHL provides important protections to civilians during displacement, so its full implementation contributes to ensuring the safety and well-being of IDPs. ${ }^{51}$

- Failure to respect IHL can result in civilian and military superiors being found guilty of war crimes, whether directly or under the doctrine of command or superior responsibility. ${ }^{52}$

- National criminal law prohibitions relating to displacement can be included in military manuals, training curricula and briefing modules.

\section{For other actors}

Recommendation 5: International and humanitarian organizations should continue to offer technical advice and support to AU Member States, not only for ratification of the Kampala Convention, but also for the full range of domestic implementation measures required under national legal and policy frameworks.

- Many States have already benefited from this advice and support and/or continue to express an interest in receiving it.

- When offering their advice and support, organizations can usefully share good practices initiated by other States and/or facilitate peer-to-peer exchanges and the sharing of experiences between States directly. This has proven to be very effective in encouraging States to take the necessary measures to implement the Kampala Convention. It can also help streamline domestic implementation processes.

- When building the authorities' capacities, international actors can reinforce best practices in consultation with IDPs.

50 See Customary IHL Database, Rules 1, 14 and 15 and, specifically on displacement, Rules 129, 131, 132 and 133: https://ihl-databases.icrc.org/customary-ihl/eng/docs/v1_rul, consulted 11 October 2016. See also Geneva Convention relative to the Protection of Civilians Persons in Time of War, Art. 49; Protocol Additional to the Geneva Conventions of 1949, and relating to the Protection of Victims of International Armed Conflicts of 1977, Art. 85(4)(a); and Protocol Additional to the Geneva Conventions of 1949, and relating to the Protection of Victims of Non-International Armed Conflicts of 1977, Art. 17.

51 See ICRC, Advisory Service on IHL, Internally Displaced Persons and International Humanitarian Law Factsheet, ICRC, Geneva, March 2010: www.icrc.org/en/war-and-law/ihl-domestic-law/ documentation\#displaced, consulted 11 October 2016. For an overview of IHL provisions that are relevant to the protection and assistance of IDPs, see also the Annex to this report.

52 For further information on command responsibility, see: ICRC Advisory Service on IHL, Command Responsibility and Failure to Act, ICRC, Geneva, April 2014: www.icrc.org/eng/assets/files/2014/ command-responsibility-icrc-eng.pdf, consulted 11 October 2016. 
Recommendation 6: The AUC, RECs, RMs and other organizations with expertise in this domain should expand awareness-raising and capacitybuilding activities on the Kampala Convention, in coordination with States and local civil society actors. The ACHPR and its special rapporteur on refugees, asylum seekers and internally displaced persons can also play a part in this regard, in accordance with their mandates and the role attributed to them by the Convention. (See also Recommendation 3 on the role of States in promoting knowledge of the Kampala Convention and Recommendation 12 on the importance of fostering national ownership through capacity-building activities.)

- Increased public knowledge of the Kampala Convention can help expedite States' processes of ratification, domestication and operationalization of the Convention.

- RECs and RMs are often well placed to foster greater awareness of internal displacement issues, including of the potential of the Kampala Convention to prevent and address internal displacement.

- The AUC, RECs, RMs and other organizations concerned should consider approaching States to champion the Kampala Convention and share their experiences with other States.

- Local civil society actors are typically cost-effective partners with solid knowledge of the context. As such, they can contribute positively to the implementation of public awareness-raising and capacity-building activities by international actors.

- The ACHPR and its special rapporteur on refugees, asylum seekers and internally displaced persons are both expressly mentioned in the Kampala Convention. They are assigned specific roles in supporting and monitoring States Parties' implementation of the Convention. ${ }^{53}$ Thus, the ACHPR and the special rapporteur are both well placed to usefully contribute to the promotion and national implementation of the Kampala Convention, in cooperation with the AUC and others.

- Awareness-raising and capacity-building activities should be carried out with internally displaced communities as part of a meaningful and regular dialogue with those communities.

53 Articles 8(3)(e) and (f) of the Kampala Convention provide that, in order to support States Parties' efforts to protect and assist IDPs under the Convention, the AU shall inter alia share information on situations of internal displacement with the ACHPR, and cooperate with the special rapporteur on refugees, asylumseekers and internally displaced persons in addressing IDP-related issues. Article 14(4) of the Convention refers to the reporting mechanism under Article 62 of the African Charter on Human and Peoples' Rights and the voluntary procedure of the African peer-review mechanism. It establishes that, in complying with such mechanisms, States party to the Kampala Convention shall submit information on the legislative and other measures taken to give effect to the Convention. 
Recommendation 7: The AUC and AU Member States should ensure that the first Conference of States Parties takes place as soon as possible and adopts a comprehensive plan of action/road map on the operationalization of the Kampala Convention.

- Article 14(1)-(3) of the Kampala Convention provides for the establishment of a Conference of States Parties as the Convention's main monitoring body to convene regularly under the auspices of the AU. The first meeting of the Conference of States Parties will be a historic demonstration of the political will within Africa to address the issue of internal displacement proactively and collectively. It will confirm the AU's strong leadership in this regard.

- The Conference will have numerous practical benefits. It will offer States Parties the opportunity to exchange experiences of ratification and implementation of the Kampala Convention. It will also allow States Parties and invited international and humanitarian organizations to consider together how to best address the challenges of prevention and response to internal displacement in Africa.

- Furthermore, the Conference can be an important source of information for States considering ratification, and particularly for those that have already signed the Convention but have not yet joined it.

- The first meeting of the Conference of States Parties could help establish shared reporting and monitoring mechanisms and supervisory functions for the Convention, as foreseen in Article 14. A permanent Kampala Convention Secretariat could be established to these ends.

- The first meeting of the Conference could conclude with the adoption of a comprehensive road map (or plan of action) for the full implementation of the Kampala Convention, with benchmarks and timeframes. ${ }^{54}$ This could include, for example, detailed plans on the various vulnerable sub-groups within the internally displaced population that require protection and for the collection and analysis of data by sex, age and other relevant factors. This road map could then be regularly reviewed at, and between, subsequent meetings of the Conference of States Parties in the future.

54 In July 2010, the AU Roadmap for Implementation of the Outcomes of the AU Special Summit on Refugees, Returnees and IDPs in Africa (that is, the 2009 Summit that adopted the Kampala Convention, jointly with the Kampala Declaration on Refugees, Returnees and Internally Displaced Persons in Africa) was adopted for the period 2010-2015. The roadmap called for speedy ratification of the Kampala Convention, development of an action plan, implementation and revision of the action plan based on experience. See Brookings-LSE Project on Internal Displacement, United Nations Office for the Coordination of Humanitarian Affairs (UNOCHA), Forum on the African Union Convention for the Protection and Assistance of Internally Displaced Persons in Africa (Kampala Convention), Kampala, 17 June 2011: www.brookings.edu/wp-content/uploads/2012/04/Forum-on-African-Union-IDP-Convention-

Kampala-2011-Report-2.pdf, consulted 29 October 2016. See also United Nations Human Rights Council, Report of the Special Rapporteur on the Human Rights of Internally Displaced Persons (2016), op. cit. 
- AU Member States should ensure that the work of the Conference of States Parties and the road map fall within the AU's Humanitarian Agenda 2063 and the Common African Position on Humanitarian Effectiveness and its Ten-Year Action Plan. These should take into account the various African Human Rights Mechanisms and the roles they play in ensuring conditions necessary for the protection of IDPs as a specifically vulnerable group.

\section{Planning, management and monitoring of protection and assistance activities}

\section{Summary of key obligations}

(a) Designate an authority or body, where needed, responsible for coordinating activities aimed at protecting and assisting IDPs and assign responsibilities to appropriate organs for protection and assistance, and for cooperating with relevant international organizations or agencies, and civil society organizations, where no such authority or body exists (Art. 3.2(b));

(b) Provide necessary funds for providing assistance and protection to IDPs (Art. 3.2(d));

(c) Assess the needs of IDPs, including through consultation with them, and facilitate participation of IDPs in decisions regarding their assistance and protection (Art. 5.5; Art. 9.2(k));

(d) Monitor and evaluate the effectiveness of humanitarian assistance provided to IDPs (Art. 9.2(m)).

\section{Lessons learned}

It is essential to ensure that the designated coordinating authority or body has the necessary mandate and authority to mobilize all ministries and agencies concerned. It must be equipped with adequate resources (human and financial) to function effectively.

The coordination structures and processes that are put in place to address situations of internal displacement must be clearly defined to ensure effective information-sharing and decision-making at the national level between relevant ministries and agencies. They must take into account the shared responsibilities of different levels of government, especially between the central/national level and subnational/local levels. Experience indicates that regional and municipal authorities are often at the forefront of the protection and assistance response on behalf of IDPs, but may not receive adequate resources and support on a timely basis. Finally, the roles of actors outside government (whether IDP communities or civil society organizations) should also be recognized and incorporated in coordination processes.

At the same time, without well-designed and well-managed normative and policy frameworks and national coordination bodies/processes, States facing situations of internal displacement may have difficulty in maintaining donor 
interest and support for programmes. Contrariwise, States that demonstrate efforts to ensure good governance in relation to IDP matters can expect to see positive interest from donors.

It is also clear that international actors (e.g. UN agencies, ICRC, NGOs) can play important roles in supporting the development of national strategies and policies to respond to situations of internal displacement. However, if they lead rather than accompany national authorities, there is a risk that the authorities will not have sufficient ownership to carry forward the strategies and policies into the implementation phases. A genuine partnership between national authorities and international actors, consistent with the State's primary responsibility towards IDPs under its jurisdiction, is likely to produce more sustainable results. The good will of international actors is no substitute for the political will and commitment of authorities to prevent and address internal displacement.

There are strong indications that responses are most effective when there is availability of solid data on the needs, vulnerabilities and capacities of IDPs, including disaggregated data by sex, age and other relevant factors, which can constitute an agreed-upon baseline for all actors involved in the response.

\section{Some examples of good practices}

The National Strategy for IDPs in Mali specifically addresses the potential roles of the international community, including humanitarian and development actors. Art. 5(2) of the Strategy underlines the call of the UN secretary-general to humanitarian and development actors to support the government of Mali in the application and implementation of the Kampala Convention. ${ }^{55}$

Also in Mali, the Ministry of Solidarity and Humanitarian Action, which is responsible for IDP-related matters, has representatives not only in the capital, but also at regional and local levels. This helps ensure good coordination and cooperation between the national and local levels, and reflects the important roles local administrations can play in facilitating assistance to IDPs.

In South Sudan, new legislation provides for the mandate of the RRC. The role of the RRC is one of coordination of humanitarian agencies and humanitarian work, and its mandate extends to coordinating relief, rehabilitation, resettlement and reintegration of IDPs and returnees. ${ }^{56} \mathrm{RRC}$ local structures have been formed and deployed in the country. Going forward, it will be useful to regard the developing policies of the RRC for an assessment of the impact of this Commission's role in implementing the principles at the heart of IDP protection.

55 Republic of Mali, Ministère de la Solidarité, de l'action humanitaire et de la reconstruction du Nord, Stratégie Nationale de gestion des personnes déplacées internes et des rapatriés, Bamako, May 2015: www.globalprotectioncluster.org/_assets/files/field_protection_clusters/Mali/files/strategie-nationalede-gestion-des-pdis-et-des-rapatries-28-mai-2015.pdf , consulted 11 October 2016. See also: Conseil Supérieur de la Diaspora Malienne (CSDM), Assistance humanitaire aux réfugiés et déplacés de la crise malienne, Bamako, 15 August 2016: www.csdmalienne.org/actualites/assistance-humanitaire-aux-refugieset-deplaces-de-la-crise-malienne/, consulted 11 October 2016.

56 Government of South Sudan, Relief and Rehabilitation Commission Act 2016, additional information available at: www.icnl.org/research/monitor/southsudan.html, consulted 25 October 2016. 
In Somalia, a comprehensive national Policy Framework on Displacement was developed in 2014. This includes provisions for early warning, data collection and designation of roles within the national authorities. ${ }^{57}$

The Arusha Peace and Reconciliation Agreement for Burundi includes multiple provisions relating to the protection and assistance of IDPs. These include provisions related to responsibilities for humanitarian aid and to access and security for international personnel..$^{58}$

In Nigeria, the Humanitarian Coordination Forum and its sector-specific working groups are active at the federal level and in many of the states in the north-east, including the three states most affected by internal displacement (Borno, Adamawa and Yobe). The coordination forums have helped to improve regular information exchange between all stakeholders involved in protection and assistance for IDPs. All actors should continue to strengthen these forums and improve coordination.

In addition, IDPs in many of the camps in Yola and Maiduguri participate in decisions regarding their assistance and protection through camp chairmen and chairwomen. These positions have been created by the IDPs in the camps so that the views of both male and female IDPs are taken into account.

Also in Nigeria, considerable efforts have been made by national stakeholders, with support from the IOM, to implement the Data Tracking Matrix. This tool has provided a reference base line of the number of IDPs in the north-eastern region of the country, enabling more informed programming. Further efforts should be taken to ensure accurate data in areas that are harder to access for security reasons.

In Zambia, the authorities have established a Disaster Management and Mitigation Unit, which reports to the vice-president and receives funds every year. ${ }^{59}$

In Burkina Faso, CONASUR, the government body responsible for disaster response, has been able, together with donors, to respond effectively and rapidly to short-term crises. Having a standing structure in place certainly improves a State's capacity to respond to emergencies, and allows for an accumulation of experience and the development of standing procedures.

Where legislative or other delays mean that an appropriate coordination structure for IDPs is not established, other existing structures can, in some cases, be adapted to provide practical responses to the needs of IDPs. This can prove useful, although it does not diminish the importance of coordination structures and bodies specifically established for the purpose of dealing with internal displacement. Thus in Chad, the CNARR, has, in practice, played some role in relation to IDPs. In Liberia, the Refugee Commission would be mobilized in cases of internal displacement.

57 See J. Drumtra, Internal Displacement in Somalia, op. cit., pp. 16-17.

58 Arusha Peace and Reconciliation Agreement for Burundi, op. cit., Protocol III, Art. 26, and Protocol IV, Art. 2, respectively.

59 Government of Zambia, Disaster Management and Mitigation Unit, Office of the Vice-President. See www.dmmu-ovp.gov.zm/?page_id=18, consulted 24 October 2016. 
In some countries, such as Rwanda and Ethiopia, State authorities have agreements with their country's NS for initial assessment and rapid response at the outset of a displacement situation. This type of agreement can be very valuable in that it can, in advance, serve to put in place plans and resources needed to respond to sudden emergencies.

There have been positive experiences in a number of contexts with the use of collaborative profiling exercises (e.g. those led by the JIPS in the field). ${ }^{60}$

\section{Key challenges}

In a number of States, processes and plans for a coordination body have been developed and sometimes approved, but not fully implemented. Reasons for this may include delays in appointing key personnel and a lack of funds, political will or agreement on the roles of the coordination body or departments or agencies concerned.

In several contexts, States have established a coordination body for IDP issues but have failed to adequately fund it, whether from State resources (annual or ad hoc funds) or from partner/donor funding.

Furthermore, a coordinating body for refugee response or disaster risk reduction/response has been established in some countries, but not explicitly mandated to address IDP issues. During internal displacement crises, this body may de facto (or by default) be tasked with responding. Although this may prove useful, there are risks that the coordinating body may lack either the authority or resources to address IDP issues effectively.

Many States experience difficulties in establishing and maintaining the required level of dialogue with internally displaced communities. This can be the result of various factors, ranging from it not being seen as a priority to inadequate policies and structures and security/access concerns, etc. This can undermine the authorities' ability to implement programmes that respond to the needs of IDPs on the ground using available resources in the most efficient way.

A related difficulty arises when the IDP representatives (e.g. the IDP committees or chairpersons in camp settings) with whom the authorities engage, do not fully reflect the composition and views of the entire displaced community. It is often the most marginalized or vulnerable sub-groups with specific needs (e.g. women, the elderly and the disabled) who are not well represented. This can make it hard for authorities to accurately assess the range of existing needs.

Ensuring accurate assessments and planning well-targeted assistance and protection programmes in a timely manner outside major urban areas is often a challenge. Experience shows that the greatest knowledge and technical skills to perform needs assessments and plan assistance activities tend to be concentrated in the capitals or major cities. When IDPs are located outside these areas, it can be harder to address their needs. 
Another challenge frequently faced in implementing effective responses is the lack of solid and comprehensive data on the needs, vulnerabilities and capacities of IDPs in a given context. This includes disaggregated data (by sex, age or other relevant factors) that can constitute an agreed-upon baseline for all actors concerned. There can be many obstacles to the identification of IDPs and adequate data collection. These can include IDPs' frequent dispersion with host families and communities, the lack of access to internally displaced communities by authorities or humanitarian actors, ${ }^{61}$ or IDPs seeking anonymity for protection reasons. Where an overly restrictive definition of IDPs is adopted, this may result in data that does not accurately reflect the scope of the problem.

\section{Recommendations}

\section{For States}

Recommendation 8: States should take steps to ensure that the designated coordinating authority or body has the necessary mandate and legitimacy to mobilize all ministries and agencies concerned, and is granted adequate resources (human and financial) to function effectively.

- It is essential that a State's normative and policy frameworks on IDPs are accompanied by the right government structure to operationalize these frameworks.

- The precise arrangements will vary from State to State, but in every case the designated authority must have the mandate and legitimacy needed in a given State to be effective.

- Of particular importance are the arrangements for cooperation and coordination between ministries and agencies at the national level, as well as between the national and local levels.

- Without sustained political will, even the best-designed coordination body for IDP responses is unlikely to ever be - or remain - effective in assisting and protecting IDPs.

- The designated authority must also consistently - or in times of a crisis - have adequate financial and human resources, so as to be in a position to translate the laws and policies into concrete action.

- It is in the interest of every State to have the best available information about the needs of people under its jurisdiction, especially those who are vulnerable because of internal displacement. 
Recommendation 9: Public authorities should develop adequate capacities at all levels to gather and maintain solid and current data on the needs, vulnerabilities and capacities of IDPs, as well as on durable solutions, including disaggregated data (by sex, age and other relevant factors). (See also Recommendation 18 on the importance of authorities maintaining an IDP register.)

- The availability of solid data leads to more effective and targeted responses, translating into better assistance and protection for the displaced. When all the actors concerned support the data analysis, this can provide a valuable common baseline for coordinated programming. ${ }^{62}$

- States that engage in collaborative data collection and analysis with international actors will strengthen their own capacities in this domain. In addition, they will be able to help ensure that data is collected, analysed and understood with the benefit of accurate knowledge of the context and the displacement-affected communities concerned.

- Data on durable solutions (e.g. which solutions IDPs would prefer in a given context, numbers of people who have integrated locally, pursued return, etc.) is also very important. This not only helps ensure a better response in a given context, but also provides greater insights that can be useful to improving responses elsewhere.

Recommendation 10: Public authorities should proactively ensure consultation of and active engagement with IDPs and host communities in order to ensure their participation in decision-making on actions undertaken on their behalf. This engagement should take into account the diverse profiles of the displaced population (e.g. sex, age and other factors). (See also Recommendation 22 on the importance of consultation and active engagement of IDPs in decisionmaking on durable solutions.)

- This is the single most important element in ensuring that the needs of IDPs are effectively met in each phase of their displacement. This in turn helps ensure accountability towards the people on behalf of whom activities are carried out. Accountability requires that activities respond to people's real needs and priority concerns, and make the most effective use of available resources.

- The necessary engagement starts with needs assessments, continues throughout the design and implementation of programme responses, and concludes with the monitoring and evaluation of the responses.

- Consultation of and engagement with IDPs are consistent with full consideration of their human dignity and rights. Both help reinforce the

62 Please refer to the JIPS website, www.jips.org/, for further benefits of collaborative data collection and analysis. 
agency and autonomy of IDPs themselves, individually and in communities. As a result, IDPs are able to contribute to their own protection and assistance.

- Particular attention should be paid to ensuring that women, elderly people, the disabled and minority groups are able to make their voice heard and can participate in the decision-making process.

- It is important that IDPs are actively involved, through their community leaders and chairpersons, in the management of their camps.

- Public authorities should ensure continual dialogue with IDP communities, as their needs are likely to change as the situation evolves. Consideration of the wishes and concerns of IDPs is especially important in order to provide durable solutions, which should be the result of a free and informed choice.

Recommendation 11: Public authorities at all levels with responsibilities for delivering assistance should establish mechanisms for monitoring short and longer-term outcomes. These should incorporate appropriate elements of accountability to IDPs.

- The main advantage of establishing an effective monitoring mechanism is an improved capacity on the part of the authorities to ensure that assistance reaches those for whom it is intended, and that resources are used in the most efficient way.

- Monitoring and evaluation allows for programmes to be adjusted and adapted, as needed, so that the assistance provided responds best to the needs of IDPs.

- Effective monitoring and evaluation can involve a two-way feedback loop that allows IDP communities to provide continuous input on programming responses intended to benefit them.

- When each of the public authorities has mechanisms in place to effectively monitor the impact of assistance and ensure accountability, this can have a positive effect across government bodies, strengthening the State's capacities in overall programme delivery and accountability.

- An effective monitoring mechanism will add to donor confidence about the impact of protection and assistance activities for IDPs.

- Effective monitoring mechanisms can be used to encourage other stakeholders to establish their own mechanisms for monitoring short and longer-term outcomes of assistance.

\section{For other actors}

Recommendation 12: When supporting States to develop laws and policies including national strategies on internal displacement, other actors should favour approaches that ensure the maximum ownership on the part of the authorities. (See also Recommendation 6 on the role of other actors in awareness-raising and capacity-building.) 
- International actors must allow States to nourish a sense of ownership in the development of laws and policies, including of national strategies, to address IDPrelated situations. This can help ensure that national authorities are committed and able to advance the strategies and policies in the implementation process.

- To this effect, international actors should aim for genuine partnerships and incorporate national capacity-building into their programme objectives and schedules.

\section{Providing adequate humanitarian assistance to IDPs}

\section{Summary of key obligations}

(a) Provide IDPs with adequate food and other essential items to the fullest extent practicable and with the least possible delay (Art. 9.2(b));

(b) Provide IDPs with adequate shelter to the fullest extent practicable and with the least possible delay (Art. 9.2(b));

(c) Provide IDPs with adequate water and sanitation to the fullest extent practicable and with the least possible delay (Art. 9.2(b));

(d) Provide IDPs with adequate medical care and other health services to the fullest extent practicable and with the least possible delay (Art. 9.2(b));

(e) Provide IDPs with education and any other necessary social services to the fullest extent practicable and with the least possible delay (Art. 9.2(b));

(f) Support self-reliance and sustainable livelihood initiatives as appropriate and feasible (Art. 3.1(k));

(g) Provide assistance to host communities where appropriate (Art. 9.2(b));

(h) Facilitate rapid and unimpeded access to IDPs by humanitarian organizations (Art. 3.1(j); Art. 5.7).

\section{Lessons learned}

When States lack the necessary human and financial resources to fulfil their primary role and duty in responding to internal displacement and assisting IDPs, effective access to IDPs by humanitarian organizations is a key factor in meeting the needs of those IDPs. This must be accompanied by a commitment of state authorities and international actors to abide by humanitarian principles in providing assistance to IDPs. The importance of upholding humanitarian principles to maintain or expand access cannot be overstated.

In many places, IDPs are not accommodated in camps or other official facilities but instead stay with host families and in host communities. ${ }^{63}$ In such situations, experience shows that it is essential to consider the needs of host

63 It must be recognized that in some countries, IDPs may not seek shelter with host communities but may choose, or be obliged, to base themselves in remote and hard-to-reach areas because of security and other concerns. 
communities when assessing the needs of IDPs, as opposed to considering IDP needs in isolation. This takes into account the possible negative impact of displacement on those who receive IDPs, particularly as a result of sharing already strained resources. Acknowledging the significant contributions that host communities often give also helps to reduce or avoid possible tensions between them and IDPs.

As with other target groups, cash-based interventions on behalf of IDPs should be privileged by States and other actors, provided that local markets are functioning. Cash transfer programmes can give ownership and dignity to IDPs, allowing them to determine their own priorities and make choices on how to spend it. Further, cash enables a "virtuous cycle" at a market level, as the money provided to the beneficiaries is reinjected in the market, and resident shopkeepers benefit from it. This can result in IDPs being perceived as less of a burden by the host community.

For rural communities with farming as their main livelihood, protracted displacement to urban areas might require re-orienting their livelihood strategies to access the formal labour market. States and other actors should create opportunities for vocational training and employability in favour of IDPs, supporting registered micro-economic initiatives. In the same vein, if protracted displacement occurs in a rural area, local authorities should facilitate the official allocation of arable land for agricultural activities, in order to avoid the risk of "daily labour" exploitation.

It is important to consider that schools and other community structures can provide a short-term solution for housing IDPs. However, the communal nature of these ad hoc facilities and the lack of privacy prevent normal family cohesion in the long term. In addition, this sort of solution in the mid-to-long term will have a negative impact on access to education for the children residing in the area, as the school will not be fully available for classes. This can also be an additional source of tensions between residents and IDPs.

\section{Some examples of good practices}

In Burkina Faso, CONASUR, the government's body responsible for disaster response, has in the short term been able to provide a rapid and effective assistance response to emergencies, together with donors.

In a number of countries, humanitarian organizations are generally given rapid and unimpeded access to IDPs by State authorities.

In Rwanda, for example, the State authorities have engaged humanitarian actors in a National Platform for Disaster Risk Reduction, which meets regularly. This ongoing cooperation can help improve coordination in times of emergencies and thus improve access for the provision of humanitarian assistance to the resident and displaced communities most in need.

Also in Rwanda, the State authorities have established a structure within the government that centralises decision-making of possible requests for international assistance. The National Disaster Management Executive Committee (NDMEC), 
which includes ministries and agencies with responsibilities in responding to natural disasters, advises the Rwandan government on disaster situations where domestic capacities may not be sufficient and recommends, where necessary, that the government seek international assistance. ${ }^{64}$ Similar mechanisms can help ensure a speedy delivery of assistance as needed.

In Ethiopia, in the context of implementing the National Policy and Strategy on Disaster Risk Management, the government has established Disaster Risk Management and Food Security Committees not only in the capital, but also at the local level. These committees are directly involved in the counting of IDPs, initial assessments, compilation of figures with IOM support, and the provision of assistance through government, the Ethiopian Red Cross Society, international NGOs and humanitarian actors, such as the ICRC.

Some interesting examples have been found concerning the important issue of access to education for internally displaced children. In Mali, the national authorities have organized mobile schools (écoles itinérantes) and special examination sessions to allow internally displaced children and youth to continue their education. Also in Mali, the authorities have facilitated issuing birth certificates for displaced children in order to enrol them in school. This measure has benefited both children who needed to begin their primary education and children who were already attending school in their place of origin, but needed to go to school now in their place of displacement. In Ethiopia, local school authorities have allowed internally displaced children who did not have resident personal identity documents to attend school, thus avoiding or reducing interruptions to their education. ${ }^{65}$ Similarly, in South Sudan, the authorities have sometimes made arrangements to facilitate access to education for internally displaced children, e.g. by waiving school fees or approving curricula for schools in Protection of Civilians sites located on UNMISS bases.

\section{Key challenges}

In a number of countries, recent or current armed conflicts mean that the authorities are not functioning at their best. In some cases, there is a new government that is at the start of its mandate and thus still in the process of defining priorities and establishing effective control over, and coordination with, all the relevant departments and agencies. This may have a negative impact on the provision of humanitarian assistance to IDPs.

64 The functions of the NDMEC are provided for in Section II.3.1 of the 2009 National Disaster Management Policy (revised in 2012), op. cit. They include "taking appropriate actions when the impact of the disaster goes over the national capacity to cope with it" and "advising H.E. the president on whether to declare a national disaster and subsequently to appeal for international assistance based on information and analysis provided by NDMEC'. See also Republic of Rwanda, Law No. 41/2015 of 29/08/2015 relating to Disaster Management, Article 16, op. cit.

65 However, these ad hoc arrangements highlight the importance of States developing effective programmes to ensure that IDPs, including children, receive necessary identity and other documents to allow them to benefit from education and other services: see key obligation $(\mathrm{g})$ in the section on protection of IDPs below and Recommendation 19. 
Similarly, ongoing armed conflicts may prevent States from enabling safe access to IDPs by their own officials and agencies and/or by international and humanitarian actors. In such cases, there is also the risk that urgent military concerns may lead to overly broad restrictions on humanitarian access which are incompatible with fundamental rules of IHL.

One specific challenge is linked to the fact that States may not have adequate financial resources or a large enough pool of qualified human resources to respond to the needs of the population at the best of times. In such circumstances, the State will probably lack the capacity to respond adequately to the assistance needs of IDPs and host communities in times of crisis.

Another point to consider is that, although States may cooperate effectively with donors to respond in the short term, the lack of programmes and policies for the post-emergency phase often results in weaker responses by the State and donors alike.

Furthermore, in a number of countries, State initiatives to assess or facilitate assessment of the needs, vulnerabilities and capacities of IDPs, in cooperation with international organizations, have not been systematic.

Some States may, for various reasons, underestimate the scale or duration of an internal displacement crisis. This risks leaving urgent assistance and protection needs of IDPs unmet. It may also result in inadequate attention by States and other actors to the issue of durable solutions for IDPs. RECs and RMs may not fully realize their potential to encourage States to properly address the scale and duration of a given IDP-related situation.

Experience also indicates that, when programmes to promote self-reliance and sustainable livelihoods are absent or not sufficiently developed, IDPs are often not in a position to pursue any possible independent economic opportunities. This in turn exacerbates their dependency on humanitarian assistance, which can prolong or increase the burden of the authorities in this regard. In addition, in many of these cases, IDPs end up becoming involved in the informal economy. This can include activities that, although providing some much-needed income for internally displaced families, can have negative environmental and social consequences. It can also include some harmful coping mechanisms, such as child labour and prostitution.

There are also specific challenges in promoting self-reliance for IDPs in camp settings. One key set of constraints are security considerations, which may lead the authorities to restrict the freedom of movement of IDPs and limit the flow of goods and services in and out of camps. As a result, IDPs' ability to access livelihoods and carry out some income-generating activities (e.g. casual labour, petty trade) may be undermined.

Another example of challenges can be seen in contexts where the prolonged presence of IDPs leads to competition with host communities for scarce resources, both natural resources and public services such as health care, education and water. This can create or exacerbate tensions, in some cases adding to pre-existing ethnic, social or cultural tensions and differences. 
Finally, in some places, the lack of respect for the fundamental rules of IHL during armed conflict means that health care facilities, such as hospitals and health clinics, are not accorded due protection, and are sometimes even deliberately attacked. ${ }^{66}$ This makes access to health care for IDPs (as well as for the civilian population in general) even more challenging.

\section{Recommendations}

\section{For States}

Recommendation 13: Assessments should look at the needs and capacities of IDPs, as well as those of host communities, local authorities and services, to continuously inform the design of programme responses.

- Because host communities are so often both a key part of responses to situations of internal displacement and negatively affected by such situations, their own needs must also be addressed. The aim is to ensure their continued capacity to provide for themselves and to support those who are displaced.

- Failure to pay attention to the needs of host community can lead to heightened tensions and competition between them and IDPs. This can result in greater vulnerability for IDPs and reduced options for durable solutions.

- Assessment and monitoring of local authorities and services can allow for programming which reinforces them, rather than seeking to create parallel services which can be duplicative and more costly.

Recommendation 14: States should develop capabilities to foresee, assess and respond effectively to the multiple needs of IDPs.

- States have the primary responsibility to respond to internal displacement in an effective manner. This includes assessing the needs of IDPs under their jurisdiction and providing them with adequate humanitarian assistance, including food, water, shelter, medical care, education and access to livelihoods.

- States should seek international support where national resources are not adequate to meet the needs of IDPs. International organizations can complement and support the efforts of the authorities, especially in case of sudden and/or massive displacement. However, they cannot replace them, nor does the involvement or support of international organizations diminish a State's sovereign responsibilities towards its population.

- States should seek opportunities to develop national capacities for assessment of needs, whether within government or with trusted local partners, such as the NS. 
Recommendation 15: States should ensure that all relevant public authorities including armed and security forces - are fully informed of their obligations and instructed to facilitate rapid and unimpeded access of humanitarian organizations to IDPs. They should also ensure that IDPs can meet their basic needs (such as water, food, shelter, etc.) and access essential services (such as medical care, education, etc.)

- Discharging their obligation to assist IDPs and, where appropriate, host communities, whether independently or with the support of international actors, is an exercise of State sovereignty.

- States with limited resources will often be able to meet the needs of IDPs on their territory only with international support, particularly in case of a sudden crisis. Where international organizations' access to IDP communities, and vice versa, is hindered, the risks of serious harm to the IDPs in need become much greater.

- Besides the unacceptable humanitarian consequences, interference with humanitarian access can increase tensions between IDPs and host communities, in addition to exacerbating possible grievances and mistrust of State authorities on the part of IDP communities.

- Failure to ensure rapid and unimpeded humanitarian access may, in certain circumstances, constitute a serious violation of IHL (i.e. a war crime).

- Public authorities - including armed and security forces - should understand and respect the working arrangements of humanitarian actors, for instance, that some organizations may not be able to accept armed escorts to facilitate access to less secure areas.

\section{For other actors}

Recommendation 16: Other actors should ensure that requests for rapid and unimpeded access to IDPs by humanitarian organizations, as well as activities carried out pursuant to such access, be in full accordance with the principles of humanity, neutrality, impartiality and independence of humanitarian actors.

- Respect for humanitarian principles will best serve to guarantee effective and repeated access to IDPs and host communities for humanitarian organizations. As such, it will be of the greatest benefit to IDPs in need.

- At times, States may be cautious about the presence and activities of international organizations on their territory. Consistent respect for humanitarian principles by humanitarian actors can help mitigate this. 


\section{Protection of IDPs}

\section{Summary of key obligations}

(a) Respect and ensure the rights of IDPs to seek safety (Art. 9.2(e)) and be received without discrimination (Art. 9.2(a));

(b) Ensure that IDPs live in satisfactory conditions of safety, dignity and security (Art. 9.2(a));

(c) Respect the civilian and humanitarian character of IDP sites (Art. 9.2(g));

(d) Guarantee the freedom of movement and choice of residence of IDPs (Art. 9.2 $(f)$ );

(e) Take necessary measures to trace and reunify families separated through displacement (Art. 9.2(h));

(f) Create and maintain an updated register of all IDPs (Art. 13.1);

(g) Ensure that IDPs are issued necessary personal identity and other official documents (Art. 13.2).

\section{Lessons learned}

Across Africa, experience shows that where IDPs have access to basic communication services, they are able to reconnect with their loved ones and help each other. Only a limited number of them will need to depend on established mechanisms to find missing family members.

It is critical to note that supporting IDPs' efforts to restore contact with their family members as soon as possible can have several advantages. First, it prevents people from going missing, reduces the number of persons unaccounted for and alleviates the suffering of IDPs who do not know the fate and whereabouts of their loved ones. Second, it can reduce the burden on the authorities and humanitarian actors (e.g. the costs of providing for unaccompanied minors for extended periods of time). Finally, it may also facilitate durable solutions, insofar as families may be unwilling to relocate until missing family members are found, or conversely, may be in a better position to relocate if family links in the area of relocation are restored.

As such, ad hoc actions on restoring family links are important, for example, through liaison with the ICRC and/or the local NS, ${ }^{67}$ even in the absence of a properly structured mechanism. At the same time, every case that is resolved reduces vulnerability and can empower the IDPs concerned, so a structured strategy is warranted.

Another important lesson learned is that efficient strategies for the provision or replacement of necessary personal identity and other official documents deliver dividends in responding to urgent humanitarian needs. They facilitate medium and longer-term efforts to enable IDPs to move freely, access livelihood options and pursue durable solutions themselves. This can, in turn, facilitate family reunification. 
On a final note, investment in ensuring that IDP sites maintain their civilian and humanitarian character can bring important returns in mitigating security and vulnerability risks. The IDPs in question will enjoy better protection, which will reduce "self-defence" efforts in the camps and often benefit nearby communities alike.

\section{Some examples of good practices}

Many important provisions for the protection of IDPs were included in the comprehensive peace agreement negotiated in 2015 between the government of South Sudan and the opposition. For example, the mandate of the Transitional Government for National Unity includes expediting "the relief, protection, voluntary and dignified repatriation, rehabilitation and resettlement of IDPs". ${ }^{68}$ While these commitments have not yet been implemented, they are important undertakings concerning IDPs by the government and the opposition that may become concrete in the future.

Similarly, provisions for the protection of IDPs were also included in the 2000 Arusha Peace and Reconciliation Agreement for Burundi, which remains relevant today. ${ }^{69}$

It should be noted that, in Niger, the authorities have at times provided for the evacuation/transfer of the disabled and the elderly to safer locations. By doing so, they have complied with their obligations to protect IDPs, taking account of the special needs of some of the most vulnerable members of the displaced communities.

In Uganda, the National Strategy for IDPs expressly authorizes local authorities to issue necessary documents to IDPs. ${ }^{70}$ This includes replacement of documents lost as a result of displacement. The Strategy specifically precludes the imposition of fines or extra costs for replacing documents, or of other "unreasonable conditions". Of note, the Strategy specifies that men and women shall have equal rights to obtain identification documents, and that women have the right to have such documents issued in their own name.

In addition to States, other stakeholders can be both actors and catalysts in the development of good practice. In the Central African Republic, MINUSCA adopted a directive concerning the civilian character of IDP camps. ${ }^{71}$ This

68 Intergovernmental Authority on Development, Agreement on the Resolution of the Conflict in the Republic of South Sudan, Addis Ababa, Ethiopia, 17 August 2015, Article 2.1.2: https:/unmiss.unmissions.org/ agreement-resolution-conflict-republic-south-sudan-addis-ababa-ethiopia, consulted 10 October 2016.

69 On the continuing relevance of the Arusha Peace and Reconciliation Agreement for Burundi, see: P. Nantulya, Burundi: Why the Arusha Accords Are Essential, Africa Center for Strategic Studies, 5 August 2015: http://africacenter.org/spotlight/burundi-why-the-arusha-accords-are-central, consulted 29 September 2016.

70 Republic of Uganda, Office of the Prime Minister, Department of Disaster Preparedness and Refugees, The National Policy for Internally Displaced Persons, Clause 3.5, Uganda, August 2004: www.brookings.edu/ wp-content/uploads/2016/07/Uganda_IDPpolicy_2004.pdf, consulted 29 September 2016.

71 MINUSCA's mandate explicitly includes the protection of civilians. UN Security Council Resolution 2149 (2014), paragraph 30(a), S/RES/2149 (2014): www.un.org/ga/search/view_doc.asp?symbol=S/RES/2149\% 20\%282014\%29, consulted 13 October 2016. For further background on MINUSCA see: www.un.org/fr/ peacekeeping/missions/minusca/background.shtml, consulted 13 October 2016, and www.un.org/fr/ peacekeeping/missions/minusca/mandate.shtml, consulted 13 October 2016. 
followed a joint consideration by MINUSCA, the local authorities in Bambari and Kagabandoro, and international organizations. The directive specified the role and responsibilities of the authorities and MINUSCA in ensuring that weapons and armed groups do not find their way into IDP camps. This is an example of a multilateral arrangement that built on a State's political will.

In Nigeria, a respectful and professional screening process is used to guarantee security in the majority of the IDP camps in Yola and Maiduguri. In particular, female IDPs are screened by female police and female members of the Civilian Joint Task Force, with a view to ensuring respect for IDPs' dignity and integrity.

Also, in Nigeria the establishment of police units responsible for law enforcement activities within IDP camps in Yola and Maiduguri (including solving disputes among IDPs, such as theft, marriage-related issues and others) is a good example of a community-based initiative. These police units are composed of police officers who are themselves displaced, and reproduce the structure that was previously in place in their local government areas.

\section{Key Challenges}

Complex challenges may arise in striking the right balance between humanitarian and security considerations in regulating the movement of IDPs. This is valid with respect to IDPs' movements both en route to the place of displacement and at the place of displacement (particularly movements in and out of IDP camps), as well as in the screening of IDPs. The rights of IDPs are not always fully understood or respected in practice, with the result that consideration of these rights, when faced with security concerns, may be less rigorous than is required.

One very real and practical challenge during armed conflicts is that of maintaining the strictly civilian and humanitarian character of IDP camps and other settings. ${ }^{72}$ For example, the permanent presence of national armed forces inside a camp, which may be triggered by security concerns, may increase the risk of attacks on the camp.

National armed forces engaged in armed conflict may have legitimate reasons under IHL for considering the evacuation of civilians, namely when imperative military reasons or the security of the civilians involved so demand. ${ }^{73}$ However, in practice, their decision-making does not always take national law and international obligations with respect to civilians into account, particularly with regard to conditions of displacement (e.g. access to adequate food, shelter, water, respect for family unity) and to the fact that an evacuation can only last as long as the conditions warranting it exist. Thereafter the right to return voluntarily should be respected, though this is sometimes not the case in practice.

72 United Nations High Commissioner for Refugees, Operational Guidelines on Maintaining the Civilian and Humanitarian Character of Asylum, UNHCR, September 2006: www.refworld.org/pdfid/ 452b9bca2.pdf, consulted 29 September 2016.

73 Customary IHL Database, op. cit., Rule 129. 
Additional challenges can be found in some countries where authorities fail to establish a systematic approach to family reunification. In such circumstances, public officials-especially at the local level-sometimes refer cases to humanitarian organizations. However, this remains ad hoc and falls short of the State's obligations in this regard.

It is imperative to highlight that, in armed conflicts, internal displacement exacerbates the vulnerability of IDPs to certain types of abuses, which underscores the importance of upholding IHL rules. In particular, it increases the risk of sexual violence, whether in IDP camps or elsewhere.

Experience indicates that, in several contexts, IDPs face difficulties in obtaining official documents - whether regular personal identity, residence documents or special documents which recognize their displaced status and facilitate access to services accordingly. The causes for this can vary, from insufficient personnel in public offices in regions crowded with IDPs, to an overly strict reliance on rules concerning provision of documents, e.g. that they be issued only in the IDP's habitual place of residence. Whatever the causes, the lack of official documents can limit IDPs' freedom of movement and access to livelihood options. In addition, the lack of documents can restrict access to education for IDP children and youth, and can also, as noted elsewhere in this report, impede family reunification.

\section{Recommendations}

\section{For States}

Recommendation 17: States should ensure that all relevant public authorities including armed and security forces - are fully informed of their obligations and instructed to facilitate freedom of movement and residence of IDPs.

- Freedom of movement involves both the ability to reach a safe place and then, once there, the ability to move freely in and out of the displacement location to access essential services, goods, employment and to restore or maintain family links.

- While there is a recognized need to strike a balance between humanitarian considerations and security concerns, the right to freedom of movement and residence needs to be considered fundamental for IDPs, just as it would be for other citizens or residents of any State.

- Greater freedom of movement increases the capacities of IDPs to move according to their own priorities and to become self-reliant. ${ }^{74}$ This potentially

74 Internal Displacement Monitoring Centre, Protracted Displacement: Uncertain Paths to Self-Reliance in Exile, IDMC, Geneva, September 2015: www.internal-displacement.org//publications/2015/ protracted-displacement-uncertain-paths-to-self-reliance-in-exile, consulted 29 September 2016. 
reduces the burdens on host communities, camp facilities and, ultimately, State authorities.

- Conversely, undue restrictions on freedom of movement of IDPs can increase the humanitarian needs of IDPs and host communities alike.

Recommendation 18: Public authorities should develop adequate capacities at central and local levels to create and maintain an updated register of all IDPs. This can provide an agreed-upon baseline for all actors concerned. (See also Recommendation 9 on the importance of data collection.)

- For protection purposes, reliable data on vulnerable individuals and families in the form of a register is vital. ${ }^{75}$

- Personal information collected in relation to the register must be compiled and handled in accordance with all relevant protection of personal data laws and standards, as well as due regard for the security and dignity of the IDPs and, where relevant, their hosts.

Recommendation 19: Public authorities should endeavour to allocate adequate efforts and resources to ensure that IDPs are able to obtain personal identity documents and other official documents within a reasonable time.

- This can help reinforce the agency and self-reliance of IDPs. It can make it possible for them to move more freely (e.g. in order to seek assistance and to get access to employment opportunities), and also to demonstrate eligibility for assistance and protection programmes.

- It helps a State fulfil its obligations to maintain a register of IDPs and to facilitate family reunification. It also contributes to accurate data collection, by allowing a State to have and analyse up-to-date information on the extent of an IDP crisis. This in turn helps a State ensure more effectively targeted assistance and protection activities.

Recommendation 20: Public authorities should strengthen their laws, policies and concrete measures to ensure that the civilian and humanitarian character of IDP sites is maintained.

75 See, for example, Internal Displacement Monitoring Centre, Getting on the List: The Registration of Children Born to IDPs, IDMC, Geneva, May 2015, available at: www.internal-displacement.org/ publications/2015/getting-on-the-list-the-registration-of-children-born-to-idps, consulted 24 October 2016. 
- This is a critical action to help ensure the protection of highly vulnerable people in IDP camps and other settings.

- International and humanitarian actors can assist States in this regard. For example, responsibilities may be shared between national armed forces and any UN forces operating in the country.

\section{For other actors}

Recommendation 21: International and humanitarian actors should provide coordinated support to States to ensure a practical and effective system to address family tracing and family reunification needs.

- Displacement often causes separation between family members.

- Many States recognize the importance of family tracing and family reunification activities, but a number of them lack specific mechanisms to carry out these activities.

- Many States are willing to receiving support and advice from international and humanitarian actors to ensure that contact can be restored between family members separated because of displacement.

- NSs are usually well placed to assist with this, often in cooperation with the ICRC. Their involvement helps to build a system to ensure that people separated from their families receive sufficient attention.

- Under humanitarian law, everyone has the right to know what has happened to his or her missing relatives and to communicate with members of their family from whom they have been separated. States bear the main responsibility for ensuring that the rights of families who have become separated are respected.

- Certain groups of people are particularly vulnerable and have specific needs to be addressed. These include children who may find themselves separated from their parents, and elderly and disabled people who may have lost contact with their care-givers and not be able to fend for themselves.

\section{Durable solutions for IDPs}

\section{Summary of key obligations}

(a) Allow IDPs to make an informed choice on whether to return, integrate locally or relocate by consulting them on these and other options and ensuring their participation in finding sustainable solutions (Art. 11.2);

(b) Promote and create satisfactory conditions for voluntary, safe and dignified return, integration or relocation on a sustainable basis and in circumstances of safety and dignity (Art. 11.1);

(c) Protect IDPs against forcible return to or resettlement in any place where their life, safety, liberty and/or health would be at risk (Art. 9.2(e)). 


\section{Lessons learned}

One usual prerequisite for durable solutions is an adequate and timely response during a crisis phase and early recovery. An inadequate response, particularly during ongoing armed conflict, can mean that the safety and protection of IDPs are not effectively guaranteed, which may result in further displacement. It may also mean that IDPs are not sufficiently supported in their efforts to re-establish their self-reliance, thus prolonging their dependence on humanitarian assistance. An inadequate crisis response may create and magnify tensions between host communities and displaced people. It can lead to security and economic problems, which in turn can limit options for durable solutions, notably, by hampering local integration. In some case, inadequate responses may be symptomatic of ineffective coordination between humanitarian and development actors. ${ }^{76}$

It is valuable for a State to anticipate and integrate durable solution considerations from the outset when responding to a situation of internal displacement. Some decisions taken in the initial stages of a displacement crisis (for example, concerning where and how to accommodate IDPs) can, at a later stage, have an impact on efforts to achieve durable solutions. From this perspective, the adoption of a comprehensive law/policy instrument in which assistance, protection and durable solutions for IDPs are simultaneously and comprehensively addressed, could be a very useful step towards ensuring a holistic approach. In the same vein, attention to durable solutions for IDPs may in some cases be most effectively addressed as part of a broader national development strategy.

Some States invest in the promotion and creation of satisfactory conditions for voluntary, safe and dignified return, integration or relocation. In general, these States achieve greater success and more sustainable results. Oftentimes, this is realized through coordinated strategies by State authorities - including the armed and security forces. It is important to highlight that sustainable results are most often achieved through realistic schedules and consultation with international, regional or national partners.

Experience has also shown that adequate and genuine consultation and dialogue with internally displaced communities are essential prerequisites for durable solutions. Without this, initiatives such as the simple closure of camps are often artificial solutions that do not result in truly durable solutions, instead leading to renewed or protracted displacement. Examples of properly planned assistance to help returnees or relocated IDPs to meet their immediate basic needs and to foster the early recovery of their livelihoods, have proven more efficient.

To be effective, consultation and dialogue on durable solutions must be based on sufficient and reliable information as to the prospects and conditions

76 See Inter-Agency Standing Committee (IASC), IASC Framework on Durable Solutions for Internally Displaced Persons, The Brookings Institution-University of Bern Project on Internal Displacement, April 2010: www.unhcr.org/50f94cd49.pdf, consulted 2 October 2016. 
for each durable solution. In this perspective, it is critical that IDPs be given access to information on conditions in their habitual place of residence in order to be able to assess realistically the viability of return. "Go-and-see" visits, where feasible, can prove useful in this regard. Threats to security in the habitual place of return (e.g. landmines and unexploded ordnance) need to be explained to IDPs and addressed by the authorities before IDPs are encouraged to consider return.

The inclusion in a peace agreement of key provisions on the protection of IDPs and durable solutions can help improve the possibilities for IDPs to have effective access to durable solutions, once core political issues are addressed.

The importance of official documents comes up again in efforts to identify and realize durable solutions. At this phase, it is often documents relating to housing, land and property that are of most concern. Here again, national authorities need to anticipate and respond to the needs of IDPs. ${ }^{77}$

\section{Some examples of good practices}

Legal protections for IDPs at the constitutional and ordinary domestic law levels are important elements in creating an environment conducive to durable solutions. For example, in Ethiopia, the constitution, the Criminal Code and the Land Administration Policy all potentially provide important protections for IDPs, which are essential for dignified durable solutions. These fundamental legal protections lay the groundwork for the more specific legal and policy measures that are required in each case.

Uganda's National Strategy contains detailed provisions regarding voluntary return and resettlement for IDPs, including on the need for "objective and accurate information relevant to their return or reintegration to their homes."78

In Central African Republic, ad hoc structures were created by the new government to study the eventual closure of IDP camps in M'poko and the return or relocation of IDPs accommodated there. This is an expression of political will to tackle the issue of durable solutions, which hopefully will give impetus to future strategies in this regard.

In Liberia, a 2014 workshop gathered key stakeholders to address how they could implement the Kampala Convention better in post-conflict Liberia. They identified a range of follow-up actions. This included a call on the Liberian government to strengthen its capacities and commit more resources to reintegration and reconciliation programmes for long-term displaced persons, including a sustainable low-cost housing programme to facilitate returns. ${ }^{79}$

77 For more information, see Centre on Housing Rights and Evictions (CHRE), The Pinheiro Principles: United Nations Principles on Housing and Property Restitution for Refugees and Displaced Persons, CHRE, Geneva, 2005: http://reliefweb.int/report/world/pinheiro-principles-united-nations-principleshousing-and-property-restitution-refugees, consulted 24 October 2016.

78 Republic of Uganda, The National Policy for Internally Displaced Persons, op. cit.

79 Internal Displacement Monitoring Centre, Domesticating the Kampala Convention: Law and Policy Making - Workshop Report (Liberia), op cit. 
The Peace and Reconciliation Agreement for Mali contains a chapter dealing with humanitarian issues, in which the parties undertake to create the necessary conditions for facilitating the rapid return, repatriation, and reintegration of internally displaced people and refugees. Humanitarian organizations and agencies are invited to support the parties' efforts in this regard. ${ }^{80}$

\section{Key challenges}

States may lack financial resources to adequately and comprehensively address the issue of durable solutions for IDP communities. In addition, States that demonstrate a readiness to assist IDPs in the short term, may not sustain interest to develop midto long-term solutions.

Specifically, in cases of protracted armed conflict, government policymaking may be focused mainly on the short/mid-term, making long-term solutions for IDPs a very low priority. In such circumstances, donors and international partners may become reluctant to provide funding and technical assistance where a State has no comprehensive strategy for durable solutions for IDPs. Yet, the longer a conflict lasts, the more necessary it becomes to engage with displaced people and other affected communities at a structural level, to reinforce their ability to live in dignity in deteriorating conditions. At times, medium and long-term activities to support infrastructure and services are the most appropriate response to meet the urgent needs of individuals.

In protracted armed conflicts, bringing parties to comply with IHL and limit the destruction and deterioration of services during the hostilities is also a key challenge. Such destruction not only leads to further deterioration of people's living conditions, but also impedes the eventual return of IDPs.

Another challenge concerns donors themselves, who may unwittingly contribute to the premature return or relocation of IDPs. This may arise where their funding terms and schedules inadvertently create pressure on State authorities to show rapid results on durable solutions. Donors' decisions to curtail "emergency funding", without ensuring effective transition to development programmes, may also lead to the same result. The importance of responding to urgent needs and long-term needs to minimize the cumulative impact of armed conflict and prevent development reversals is, however, increasingly recognized. Ensuring such humanitarian continuity requires changes to funding allocation processes, so that multi-year humanitarian financing becomes viable and reliable.

It is clear that, without regular consultation and dialogue on available solutions and an understanding of their rights and obligations, IDPs will not be able to make choices as to possible options.

In this regard, challenges can arise from decisions made to close camps without due regard for the security and wishes of IDPs. This may occur because 
not all government branches and agencies (e.g. the ministries responsible for national security, social services and the armed forces) have the same understanding of the State's obligations towards IDPs. Under such circumstances, considerations other than those related to the IDPs' rights may influence decision-making that has implications for IDPs. Similarly, challenges can arise if IDPs are encouraged to return prematurely, including through offers of assistance, without adequate information or sustainable support.

The process of achieving durable solutions often requires dealing with complex issues, such as that of land/property restitution or compensation. This can contribute to delays in the durable solution process. An additional obstacle is created by the fact that the preferred durable solution in some cases may not be feasible for the time being. This is the case, for example, where IDPs wish to return to their home, but the area is still not safe because the conditions from which their displacement originated, continue to exist. ${ }^{81}$ Sometimes, national authorities may be overly focused on promoting return without giving due consideration to other possible durable solutions, such as local integration or relocation in another part of the country.

\section{Recommendations}

\section{For States}

Recommendation 22: States should ensure that all branches and agencies of the public authorities are fully informed of the need for meaningful consultation with and active engagement of IDPs and host communities in decision-making on durable solutions. (See also Recommendation 10 on the importance of consultation with and active engagement of IDPs in decision-making).

- In crises generating internal displacement, there is most often a great deal of confusion and misinformation about the root causes and/or the way internal displacement is dealt with. There can be mistrust on the part of displaced communities as to the State's motives and priorities in responding. Regular consultation and meaningful dialogue with IDPs will enable them to better assess their options and exercise their right to make an informed choice on durable solutions, in addition to generating trust in authorities. It will also help State authorities to better understand the concerns and wishes of IDPs and communities and to address those issues of mistrust or misinformation.

- When consulted, internally displaced communities may be able to propose viable solutions that are both cost-effective for the State and sustainable.

81 Internal Displacement Monitoring Centre, Home Sweet Home: Housing Practices and Tools that Support Durable Solutions for Urban IDPs, IDMC, Geneva, March 2015: www.internal-displacement.org/ publications/2015/home-sweet-home-housing-practices-and-tools-that-support-durable-solutionsfor-urban-idps, consulted 29 September 2016. 
- Where the preferred durable solution is not feasible at a given time, the authorities should seek to facilitate transitional solutions to improve the circumstances of IDPs, in dialogue with them. In such cases, the authorities should remain mindful that IDPs do not lose their right to achieve their preferred durable solution when this becomes accessible.

Recommendation 23: States should proactively initiate dialogue with international and national partners and donors on issues related to durable solutions in order to fulfil their own international obligations.

- It is incumbent on the State in question to ensure the voluntary, safe and dignified character of all possible durable solutions. At the same time, it is recognized that international assistance may be required to realize appropriate responses.

- A proactive approach increases States' possibilities of benefiting from the experience and resources of international partners and donors and from best practices.

- In particular, this can help a State experiencing challenges with internal displacement to connect the urgent humanitarian response to a longer-term development agenda. This can often help address some of the causes and outcomes of displacement.

- The financial resources required for effective solutions can be considerable, and this needs to be openly acknowledged by all stakeholders.

Recommendation 24: States (and other relevant stakeholders) should ensure that any peace agreement contains specific provisions and recommendations on addressing and solving existing IDP-related situations, as necessary, taking into account the challenges of the context.

- This would be important to help resolve internal displacement-related problems arising from an armed conflict.

- A key aspect to be dealt with in the peace agreement and any post-conflict transitional justice processes would relate to durable solutions, such as voluntary return for IDPs. ${ }^{82}$

- Other issues may be land reform, reparations, etc., depending on the conflict.

82 For an extensive collection of peace accords, with analysis of their implementation and their content, including IDP issues such as durable solutions, see the Peace Accords Matrix Project at the University of Notre Dame: https://peaceaccords.nd.edu/about, consulted 25 October 2016. 


\section{For other actors}

Recommendation 25: The UN and other international actors that are in a position to do so, should contribute to monitoring conditions of return, with particular attention to the perspectives and concerns of the IDP communities in question. They should also help ensure the voluntary and safe character of return and other durable solutions, as well as safety, dignity and adequate conditions for IDPs in their current places.

- Public authorities may experience difficulties in establishing a meaningful dialogue with the displaced communities. In these cases, the UN and other international actors can play a useful role in engaging with IDPs to understand their perspectives and concerns.

- By doing so, important issues can be brought to the attention of the authorities. This includes the possible lack of sufficient and clear information on durable solution options that are provided to IDPs. Additionally, situations where IDPs may feel that a durable solution is being promoted prematurely by authorities, or without adequate consideration for their wishes, can also be addressed.

- Donors can often exert a positive influence by assisting States to develop realistic, mid- to long-term strategies to phase out IDP sites and facilitate return or other durable solutions.

\section{Conclusion}

The comprehensive legal framework of the Kampala Convention offers African States the opportunity to improve the daily quality of life for IDPs across the continent by addressing their protection and assistance needs effectively. States can prevent, address and reduce displacement by methodically and comprehensively implementing the Convention. They can ensure that, when displacement occurs, IDPs are provided with assistance and treated with respect for their human dignity and their rights.

This report contains more than 80 Findings and 25 Recommendations. The ICRC hopes that these will be of interest to States, depending on their own approach to the Kampala Convention. A number of major cross-cutting themes emerged in the formulation of the Findings and Recommendations, of which three merit particular mention:

1. The importance for States and other actors of engaging in dialogue with IDP communities in order to ensure their meaningful participation in decisionmaking on law, policies and programmes that affect them;

2. The urgent need for ensuring access of IDPs to essential services such as health care and education; 
3. The vital roles the AU - and RECs and RMs - will play in the future in supporting the efforts of AU Member States to fully implement the Kampala Convention.

While considerable momentum in upholding States' primary responsibility and obligations to the plight of IDPs has taken place, the Kampala Convention can only truly realize its full potential once all States across the continent have not only joined it, but have also taken the necessary steps to fully implement it. It is hoped that this report will serve to support and expedite States' ratification, implementation and operationalization of the Convention and the promise it holds for current and future IDPs in Africa.

\section{Acknowledgements}

The ICRC commissioned Robert Young as a consultant to draft this report as one of the outcomes of a stocktaking exercise on the "operationalization" of the African Union Convention for the Protection and Assistance of Internally Displaced Persons in Africa (the Kampala Convention). It contains findings and recommendations based on the input received from ICRC delegations, combined together with supporting research and consultations within the ICRC and with selected stakeholders. Robert is an international lawyer and humanitarian protection specialist. He is a former long-time ICRC Delegate, whose postings included Protection Delegate in Ethiopia, Regional Legal Adviser based in Abidjan, Côte D'Ivoire, and Deputy Head of Delegation \& Legal Adviser at the ICRC Permanent Observer Mission to the United Nations in New York. Sarah Gaines, a former staffer at the ICRC's New York Delegation and a freelance writer/editor, helped research, edit and draft the report.

For the ICRC, Angela Cotroneo, IDP Adviser in the Protection of the Civilian Population Unit, oversaw the stocktaking exercise and the writing of this report, together with Maria Ximena Londoño, Legal Adviser in the Advisory Service on International Humanitarian Law (IHL).

A special note of gratitude is offered to the numerous colleagues at ICRC delegations across Africa whose initial input, updates and additional information made this report possible. Several ICRC Legal Advisers based in field delegations provided very helpful input, as did various members of the Protection and Assistance Divisions and the Department of International Law and Policy.

The ICRC expresses its thanks and appreciation to the Chair of the African Union (AU) Permanent Representatives Committee (PRC) Sub-Committee on Refugees, Returnees and Internally Displaced Persons in Africa, for his active participation and useful comments and observations on the report's preliminary findings and draft recommendations. Thanks are also due to officials in the Department of Political Affairs at the African Union Commission (AUC), as well as representatives in Addis Ababa and Geneva of the United Nations High Commissioner for Refugees (UNHCR), the International Organization for Migration (IOM) and the Norwegian Refugee Council (NRC).

Their advice and practical concrete suggestions were invaluable in the preparation of this report. However, this does not imply any institutional or personal endorsement of, or responsibility for, the report in whole or in part, which rests only with the ICRC. 